\title{
Illuminating Innovation: From Patent Racing to Patent War
}

\author{
Lea Shaver*
}

\begin{abstract}
Patent law assumes that stronger protection promotes innovation, yet empirical evidence to test this "innovation hypothesis" is lacking. This Article argues that historical case studies hold unique promise to provide an empirical foundation for modern patent policy. Specifically, this Article uses the history of patents surrounding the light bulb to examine a recently articulated theory of "patent racing" as a justification for patent protection. Thomas Edison's experience confirms that Mark Lemley's racing model has substantial descriptive merit. Yet this case study also reveals the limits of the patent racing model. Looking past the initial finish line of patent filings to later litigation, the competition looks less like a race and more like a war.
\end{abstract}

* J.D., Yale Law School; M.A., University of Chicago; Associate Professor of Law, Indiana University Robert H. McKinney School of Law. I would like to thank Jack Balkin, Christopher Beauchamp, Joseph Blocher, Samuel Buell, Michael Carrier, Dennis Corgill, Eric Dannenmaier, Rochelle Dreyfuss, Laura DeNardis, Elizabeth Glazer, Laurence Helfer, Lauren Henry, Paul Israel, Eric E. Johnson, Mark Lemley, David S. Levine, Gerard Magliocca, Robert Mensel, Emily Morris, Adam Mossoff, Lisa Larrimore Ouellette, Jerome Reichman, Jake Sherkow, Rose Villazor, Carleton Waterhouse, and R. George Wright for their particularly helpful comments. Portions of this Article were presented at Duke Law School's Legal Theory Workshop, Hofstra Law School's Junior Faculty Forum, the Indiana University Maurer School of Law, the Information Society Project at Yale Law School, the Intellectual Property Scholars Conference at Stanford University, and on the Stanford University radio show Hearsay Culture. This Article is made available to the public under the terms of a Creative Commons-Attribution license. A digital copy may be downloaded at no charge from the Social Sciences Research Network at http://ssrn.com/ abstract $=1658643$. Copies and reprints should acknowledge first publication as: Lea Shaver, Illuminating Innovation: From Patent Racing to Patent War, 69 WASH. \& LEE L. REV. (2012), available at http://law.wlu.edu/lawreview/ and http://ssrn.com/abstract=1658643. 
The Article then proposes a new model of "patent warfare" resembling the board game Risk. In the game, competing parties assemble strategic assets, then turn to battle their rivals for world domination. Similarly, innovative technology companies assemble patent portfolios-initially for defensive purposes in the context of a dynamic and competitive field. As an industry matures, however, dominant players convert their shields into weapons to eliminate their competition. Just as nineteenth-century companies in the early electrical industry battled to control the light bulb, a new patent war is now emerging to control the smartphone. This anticompetitive endgame diminished next-generation innovation in electric light and now threatens the future of innovation in mobile computing.

A new appreciation of patent warfare should prompt increased skepticism of the "innovation assumption" at the heart of patent law. Patent protection clearly provides short-term benefits to innovation, but it also produces unanticipated longterm costs to competition and next-generation innovation. Further empirical research is needed to ascertain whether the benefits outweigh the costs or vice versa and what tweaks to the patent system might allow us to continue to capture the benefits while lowering the costs. In this continued effort, historical case studies will prove particularly helpful because they permit insight into the complex workings of patent law on an industry over a longer time horizon, revealing not only the short-term benefits but also the long-term costs.

\section{Table of Contents}

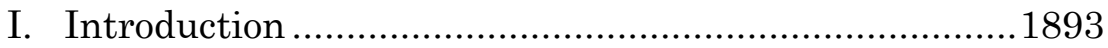

II. Testing the Innovation Hypothesis .............................1896

A. Patents and Innovation ....................................... 1896

B. Case Study as Methodology ..................................1900

C. Law and the Light Bulb ........................................1907

III. Dynamics of Inventive Races ................................... 1911

A. The Theory of Patent Racing...............................1913

B. Support for Patent Racing Theory ........................1915

C. Problems for Patent Racing Theory ....................... 1921 
IV. Learning from the Light Bulb .................................... 1926

A. From Patent Racing to Patent War ....................... 1926

B. The Current Smartphone Patent War .................... 1933

C. Implications for Innovation................................. 1944

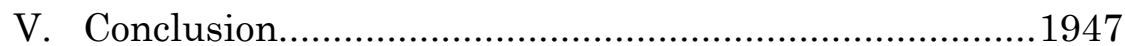

\section{Introduction}

More than a century after its introduction, the incandescent light bulb remains the defining icon of invention. Elegantly simple, this humble device was nonetheless a transformative technology. ${ }^{1}$ Just as spreadsheet software drove demand for personal computers and email clients drove demand for Internet service, the incandescent lamp was the "killer app" that drove demand for electricity. ${ }^{2}$ In the process, the light bulb paved the way for every other electronic appliance, including the radio, the television, and the personal computer. No less than the computer, the light bulb revolutionized our world.

This Article sheds light on the role that patent law played in the light bulb's emergence. The story told here is not a conventional tale of great inventors, bright ideas, and the inevitable march of scientific progress. It is a story of corporate maneuvering and high-stakes litigation, as Thomas Edison and

1. For greater discussion of the concept of "enabling technologies," see Mark A. Lemley, Patenting Nanotechnology, 58 STAN. L. REV. 601, 606-13 (2005).

2. See Arthur A. Bright, JR., The Electric-Lamp Industry: Technological Change and Economic Development from 1800 to 1947 8-11 (1949) (explaining the importance of the incandescent lamp to the emergence of an electrical supply system, scientific and public interest in electricity, the radio, and economic growth through World War I generally). Edison himself played a great role in developing and building out the technology and infrastructure for electricity distribution. Of Edison's patents related to electric light between 1881 and 1883, only $37 \%$ were related to the light bulb. The majority of his patents related to other elements of the electric power delivery system, including voltage regulation and engine governors (24\%), transmission and distribution (14\%), and dynamo design and operation (12\%), among other aspects. Paul Israel, Claim the Earth: Protecting Edison's Inventions at Home and Abroad, in Knowledge Management And Intellectual Property: Concepts, ACtors and Practices from the Past to the Present (Graham Dutfield \& Stathis Arapostathis eds., 2013) (forthcoming) [hereinafter Israel, Claim the Earth] (on file with author). 
his competitors employed patents as weapons in their battle to dominate the electrical industry. Although famous for his workshop talents, Edison would be better understood as an early Bill Gates, his business success built on a keen appreciation of the power of aggressive intellectual property strategy and the frailty of antitrust law. ${ }^{3}$

This story holds particularly important lessons for the modern information technology (IT) industry, where an epic patent battle is now underway. ${ }^{4}$ Although early incandescent

3. See generally William H. Page \& John E. Lopatka, The Microsoft Case: Antitrust, High Technology, AND Consumer Welfare (2007) (examining the antitrust case against Microsoft in the context of shifting debates about antitrust law); see also Israel, Claim the Earth, supra note 2 (explaining that Edison used patents as part of a larger strategy to establish industry dominance through his early work in the telegraphy industry, strategically identifying certain technological features of the electrical system as choke points for where to achieve "the commercial monopoly of the general [electricity] distribution business").

4. As this Article went to print in December 2012, Apple had recently won a $\$ 1$ billion judgment against Samsung for intellectual property infringement related to smartphones and tablets running Google's Android operating system. This Apple-Samsung trial, completed in August 2012, is just one among dozens in a broader pattern of transnational litigation. See generally Andy Baio, A Patent Lie: How Yahoo Weaponized My Work, WiRED (Mar. 13, 2012, 3:44 PM), http://www.wired.com/epicenter/2012/03/opinion-baio-yahoo-patent-lie/ (last visited Nov. 14, 2012) (on file with the Washington and Lee Law Review); Michael A. Carrier, A Roadmap to the Smartphone Patent Wars and FRAND Licensing, CPI ANTITRUST CHRON., Apr. 2012, available at http://papers.ssrn.com/sol3/ papers.cfm?abstract_id=2050743; Robert McMillan, How Apple and Microsoft Armed 4,000 Patent Warheads, WIRED (May 21, 2012, 6:30 AM), http://www. wired.com/wiredenterprise/2012/05/rockstar/ (last visited Nov. 14, 2012) (on file with the Washington and Lee Law Review); Marissa Oberlander, Martin Stabe \& Steve Bernard, The Smartphone Patent Wars, Fin. Times (Oct. 17, 2011, 5:43 PM), http://www.ft.com/intl/cms/s/2/de24f970-f8d0-11e0-a5f7-00144feab49a.ht ml\#axzz25KFyAXEL (last visited Nov. 14, 2012) ("Patent wars are raging in the smartphone industry. What began as Apple v Google Android conflict has turned into a vast legal quagmire involving everyone from Amazon to ZTE.") (on file with the Washington and Lee Law Review); Richard A. Posner, Why There Are Too Many Patents in America, Atlantic (July 12, 2012, 10:20 AM), http://www.theatlantic.com/business/archive/2012/07/why-there-are-toomany-patents-in-america/259725/ (last visited Nov. 14, 2012) [hereinafter Posner, Too Many Patents] (on file with the Washington and Lee Law Review); Jessica E. Vascellaro \& Evan Ramstad, Apple, Samsung Set Patent Talks: Settlement Attempt Unlikely to Bear Fruit, WALL ST. J. (May 21, 2012, 9:59 AM), http://online.wsj.com/article/SB10001424052702303879604577414832794580586. html (last visited Nov. 14, 2012) ("Chief executives... will meet in San Francisco Monday in a court-directed session aimed at settling their smartphone patent war. But a deal seems unlikely, people familiar with the 
light bulbs and modern smartphones are very different technologies, they have much in common from the perspective of patent strategy. Understanding the patent war over the light bulb can help us understand what is at stake in the current war over the smartphone. ${ }^{5}$

Edison's lamp can also shed light on one of the most challenging questions asked in patent scholarship today. Is patent protection on the whole helpful or harmful to innovation? And how might the law be tweaked to achieve an even better balance between protection and competition? The light bulb can illuminate these questions by testing existing theory and helping to improve on it. For more than two centuries, U.S. patent law has assumed that patents promote innovation. ${ }^{6}$ Yet for all the profound impact that patent law has on industry and society, we have little empirical evidence to test this "innovation assumption." In fact, there are good reasons to believe that patents may also impede innovation by creating barriers to competition. ${ }^{7}$ The assumption should more prudently be treated as a hypothesis in need of empirical testing.

Part II of this Article argues that careful case studies, particularly those drawn from history, may best advance our understanding of patent law's impact on innovation. The remainder of the Article develops such a case study, focusing on Thomas Edison's efforts to market an incandescent light bulb. Part III takes up a recently articulated theory of patent racing, using the case study to test and refine the racing model. Part IV explores the lessons of this case study for the innovation hypothesis. Here, a new model of "patent warfare" is advanced, which not only explains the experience of the early electrical

matter and others tracking the battle say.") (on file with the Washington and Lee Law Review).

5. This insight becomes even more timely in light of Judge Posner's recent ruling in the Apple-Google litigation. See infra notes 183-84 and accompanying text (discussing Judge Posner's decision to dismiss the recent suit between Apple and Motorola for lack of an adequate, acceptable remedy).

6. See generally Bruce W. Bugbee, Genesis of American Patent And COPYRIGHT LAW 60-103 (1967).

7. See infra Part II.A (discussing the economic and social costs of a patent system). 
industry, but also reveals the high stakes of the new patent war now breaking out in the smartphone industry.

\section{Testing the Innovation Hypothesis}

\section{A. Patents and Innovation}

For more than two centuries, the notion that patent protection encourages technological innovation has remained the conventional wisdom. ${ }^{8}$ In 1830, Anglo-American legal philosopher Jeremy Bentham captured its essence: "In new inventions, protection against imitators is not less necessary than in established manufactures protection against thieves. He who has no hope that he shall reap will not take the trouble to sow."9 A half-century later, the same notion is reflected as the popular wisdom of industrial Americans in Mark Twain's A Connecticut Yankee in King Arthur's Court. ${ }^{10}$ In this tale, a New England

8. This utilitarian argument has never been the only justification for patent protection. Adam Mossoff has persuasively argued that normative concepts of fairness, not expectations of economic benefit, have been a significant-perhaps even primary-justification for patent protection since the founding of America. See Adam Mossoff, Who Cares What Thomas Jefferson Thought About Patents? Reevaluating the Patent "Privilege" in Historical Context, 92 CoRnell L. REv. 953, 954-59 (2007). For a recent and thorough treatment of ethical justifications for intellectual property not relying on the innovation assumption, see generally ROBERT P. MERGES, JUSTIFYING InTELlectual Property (2011). Of course, patent protection can also be challenged on ethical grounds, including notions of human rights. See, e.g., Lea Shaver, The Right to Science and Culture, 2010 Wisc. L. REV. 121, 122-28. Nonetheless, the empirical assumption that patent protection will promote technological progress finds expression in the U.S. Constitution, which provides that Congress may offer inventors monopoly privileges on their inventions for limited times "to promote the Progress of Science and useful Arts." U.S. CONST. art. I, $\S 8$, cl. 8. At the Constitution's signing, a number of states were already granting patents and some had done so even as British colonies. See BugBEE, supra note 6, at 57-103 (describing the early patent system in colonial America). The true effect of this constitutional provision, then, was not to create a governmental power to grant monopolies, but to establish this power as an exclusively federal one, to be exercised by the legislative branch. See BUGBEE, supra note 6, at 129-31 (explaining the establishment of a federal patent system). Whether the provision also established meaningful limits on the term of such monopolies is a topic that remains open to substantial debate.

9. Jeremy Bentham, The Rationale of REWARD 318 (1830).

10. Mark Twain, A Connecticut Yankee In King Arthur's Court (Oxford Univ. Press 2008) (1889). 
mechanic from the 1880s travels back in time to Camelot, where he becomes a valued advisor to the English king. On the subject of technological innovation, Twain's hero relates:

[T] he very first official thing I did, in my administration-and it was on the first day of it, too-was to start a patent office; for I knew that a country without a patent office and good patent laws was just a crab, and couldn't travel any way but sideways or backwards. ${ }^{11}$

As an empirical matter, however, the benefits of patent protection for innovation are far less certain. Scholarly skepticism about the anticipated benefits of patent protection also has deep roots. ${ }^{12}$ In the 1950 s, the noted economist Franz Machlup advised Congress:

If we did not have a patent system, it would be irresponsible, on the basis of our present knowledge of its economic consequences, to recommend instituting one. But since we have had a patent system for a long time, it would be irresponsible, on the basis of our present knowledge, to recommend abolishing it. ${ }^{13}$

Fifty years later, noted scholar Richard Posner lamented that economists have still not determined whether the benefits of intellectual property protection outweigh the costs. ${ }^{14}$ Economists

11. Mark Twain, A Connecticut YankeE In King Arthur's Court 107 (1st ed. 1889). Credit is due to Mark Adelman for leading me to Twain's work. For a more serious interview with Mark Twain suggesting that the Yankee hero's statement reflects Twain's own beliefs rather than simply words thrust upon a satirical strawman, see MARK TwaIn, MARK Twain: The COMPLETE INTERVIEwS 295 (Gary Scharnhorst ed., The University of Alabama Press 2006) (using historical evidence himself to suggest that patent protection encourages not so much invention itself as the diligent perfection of invention into a commercially practical technology). Twain was also a patent holder. See Improvement In Scrap-Books, U.S. Patent No. 140,245 (filed May 7, 1873) (issued June 24, 1873) (disclosing a self-pasting scrap-book).

12. See, e.g., Mark D. Janis, Patent Abolitionism, 17 Berkeley Tech. L.J. 899, 901-03 (2002) (analyzing parallels between the Victorian-era British movement to abolish patents and contemporary debates).

13. Fritz Machlup, An Economic Review of the Patent System: Study of the Subcommittee on Patents, Trademarks, And Copyrights 80 (1958).

14. See, e.g., Richard A. Posner, Intellectual Property: The Law and Economics Approach, 19 J. ECON. PERSP. 57, 59 (2005) ("Unfortunately, economists do not know whether the existing system of intellectual property rights is, or ... whether any other system of intellectual property rights would be, a source of net social utility, given the costs of the system and the existence 
and legal scholars have recently devoted great theoretical attention to clarifying the ways in which patent protection may inhibit innovation, as well as incentivize it. ${ }^{15}$

of alternative sources of incentives to create such property.").

15. See, e.g., Yochai Benkler, The Wealth of Networks: How Social Production Transforms Markets AND FreEdom 35-41 (2006) (analyzing the digital environment with the "understanding that markets based on patents or copyrights involve a trade-off between static and dynamic efficiency"); MICHELE Boldrin \& David K. Levine, Against Intellectual Monopoly 206 (2008) (offering a litany of economic arguments against patents and copyrights and concluding that "the patent system destroys productive capacity, generates useless and damaging monopoly, and last but not least, humiliates and destroys decent and humble geniuses"); James Bessen \& Michael J. Meurer, Patent Failure: How Judges, Bureaucrats, and Lawyers Put InNovators at Risk 145-46 (2008) ("It is important to emphasize that our evidence suggests that patents today constitute a brake on innovation, not a roadblock.... [O] ur evidence implies that patents place a drag on innovation. Without this drag, the rate of innovation and technological progress might have been even greater, perhaps much greater."); ADAM B. JAFFE \& JOSH LERNER, INNOVATION AND ITS Discontents: How Our Broken Patent System Is Endangering InNovation AND PRogress, AND What TO Do ABout It 2 (2004) (arguing that innovation is threatened by the uncertainty created by a patent system that provides poor notice of property boundaries); William M. LANDES \& Richard A. Posner, The Economic Structure of Intellectual Property LaW 11-24 (2003); Dan L. Burk \& Mark A. Lemley, Policy Levers in Patent Law, 89 VA. L. REv. 1575, 1597-99 (2003); Rochelle Cooper Dreyfuss, Does IP Need IP? Accommodating Intellectual Production Outside the Intellectual Property Paradigm, 31 CARDOZO L. REV. 1437, 1465-73 (2010) (surveying contexts in which intellectual production flourishes without intellectual property as well as reasons to believe that intellectual property may still be necessary to provide optimal incentives); Rochelle Dreyfuss, Pathological Patenting: The PTO as Cause or Cure, 104 Mich. L. REV. 1559, 1561 (2006) (reviewing Jaffe and Lerner's Book Innovation and Its Discontents: How Our Broken Patent System Is Endangering Innovation and Progress, and What To Do About It and arguing that "[w]ith some modification, [the authors' suggested reforms] could go a long way toward healing the system"); Herbert Hovenkamp, Mark Janis \& Mark A. Lemley, Anticompetitive Settlement of Intellectual Property Disputes, 87 Minn. L. REv. 1719, 1721-24 (2003) (noting that questionable patent litigation is frequently being used as cover for collusion between market competitors); Adam B. Jaffe, The U.S. Patent System in Transition: Policy Innovation and the Innovation Process, 29 RES. POL'Y 531, 531-32 (2000); Mark A. Lemley, Property, Intellectual Property, and Free Riding, 83 TEX. L. REV. 1031, 1058-59 (2005); Christopher Leslie, The Anticompetitive Effects of Unenforced Invalid Patents, 91 MinN. L. REV. 101, 103 (2006); Katherine J. Strandburg, Evolving Information Paradigms and the Global Intellectual Property Regime, 41 ConN. L. REV. 861, 871-79 (2009) (arguing that changing dynamics of innovation are poorly served by international regimes imposing substantive standards of intellectual property protection); Mark A. Lemley, Industry-Specific Antitrust Policy for Innovation 2-4 (Stanford Law \& Econ. Olin, Working Paper No. 397, 
Patent law and policy, however, continue to operate on the assumption that patents not only incentivize greater innovation, but that the patent incentive is substantial such that innovation would be greatly diminished if the incentive were removed or even weakened. ${ }^{16}$ By and large, the field of patent scholarship also treats this assumption as presumptively correct, while acknowledging that future research might one day call it into question. This willingness to assume-at least for the time beingthat patents work as intended has the same practical effect as an evidentiary presumption: it shifts the burden of proof onto the challengers of the conventional wisdom. There are virtues to adopting this assumption. One such virtue is enabling patent scholars to focus productively on calibrating less-entrenched aspects of patent doctrine and on suggesting reforms that may be implemented in the near future. ${ }^{17}$

Embracing this assumption too fully, however, carries an unacceptable risk. Patent law is a tremendously influential aspect of modern economic regulation. ${ }^{18}$ What if its central assumption is wrong? So far we have justified the substantial social costs of patent protection-litigation costs, anticompetitive effects, higher prices for consumers, barriers to adoption of new technologies-on the basis that these sacrifices are worthwhile in order to achieve faster innovation. If patent protection offers much fewer benefits for innovation than widely supposed, the law is imposing these substantial costs needlessly. And if patent protection actually has a net negative impact on innovation, the real costs to economic growth may be appalling in scale. Because the risks of being

2010), available at http://papers.ssrn.com/sol3/papers.cfm?abstract_id=1670197.

16. Indeed, evidence suggests that patent law's reliance on the innovation assumption has, if anything, increased in recent years. See Gaia Bernstein, In the Shadow of Innovation, 31 CARDOZO L. REV. 2257, 2259-60 (2010) (documenting an increasing use of the phrase "innovation" in intellectual property opinions beginning in the 1980s).

17. See, e.g., Lisa Larrimore Ouellette, Do Patents Disclose Useful Information?, 25 HARV. J.L. \& TECH. 531, 532-35 (2012) (surveying the mixed empirical support for the innovation hypothesis without taking sides and proceeding to focus on a more politically open question: What emphasis should patent doctrine place on disclosure as a central policy goal?).

18. See, e.g., BEssen \& MEuRER, supra note 15, at 6-7 (comparing the economic impact of tangible property law to economic incentives potentially created by patent laws). 
wrong are so great, the innovation assumption should more prudently be treated as the innovation hypothesis, in need of further empirical testing.

\section{B. Case Study as Methodology}

A major challenge for researchers seeking to test the innovation hypothesis is the complexity of the phenomenon. Changes in patent policy take time to play out in the marketplace and affect different industries in different ways. ${ }^{19}$ At the macroeconomic level, it can be very difficult to separate out impacts due to changes in patent policy from those due to other causes. ${ }^{20}$ Cross-national comparisons are further complicated by the trend toward harmonization of patent law, which limits opportunities for empirical evaluation of differing regimes. ${ }^{21}$ Even defining "innovation" as a quantifiable outcome has proven elusive. ${ }^{22}$ These challenges make it difficult to reliably measure patent law's impact through large-scale quantitative analysis.

19. See, e.g., Burk \& Lemley, supra note 15, at 1576-78 (explaining how innovation and therefore the impacts of patent policy differ based on the industry studied).

20. See, e.g., BESSEN \& MEURER, supra note 15, at 11 ("Many interrelated factors can influence $R \& D$ spending, innovation, and the resulting social welfare, so it is difficult to disentangle these to determine the independent influence of patents.").

21. Economist Petra Moser has creatively approached this problem by analyzing evidence of innovation predating the modern trend toward international harmonization of patent law. See Petra Moser, How Do Patent Laws Influence Innovation? Evidence from Nineteenth-Century World's Fairs, 95 Am. ECON. REV. 1214, 1231-33 (2005) (concluding that, because patent protection appears to enhance innovation in some industries but impede it in others, variance in patent regimes across countries may result in optimal global results by encouraging the development of comparative advantages).

22. In 2006, the United States Department of Commerce launched a special advisory committee to help it develop metrics for measuring the innovativeness of the United States' economy. U.S. DEP'T OF COMMERCE, ECON. \& Statistics Admin., Innovation Measurement, Tracking the State of INNOVATION IN THE AMERICAN ECONOMY (2008), available at http://www. esa.doc.gov/Reports/innovation-measurement-tracking-state-innovation-americaneconomy. The Measuring Innovation in the 21st Century Economy Advisory Committee's first meeting in February 2007 highlighted some of the challenges of measuring innovation. See Brian Wingfield, Measuring Innovation, ForBes (Feb. 23, 2007, 6:00 AM), http://www.forbes.com/businessinthebeltway/2007/02/22/ innovation-commerce-companies-biz-washington-cx_bw_0223innovate.html (last 
In my first article, I explored some of the problems inherent in macroeconomic measures of innovation, particularly the problematic reliance on rates of patent filing as the measure of innovation. ${ }^{23}$ Rather than relying on numerical data, the article suggested that careful case studies are likely to prove more enlightening at the present stage of research. ${ }^{24}$ An empirical case study steps back from the overwhelming web of data to pick up the thread of a single "case," which might be the life of a particular patent, technology, company, or industry. ${ }^{25}$ The

visited Nov. 14, 2012) (describing the first meeting of the committee) (on file with the Washington and Lee Law Review); see also Nat'L ScI. Found., Div. OF ScI. Res. Statistics, NSF 07-306, Advancing Measures of InNOvation: Knowledge Flows, Business Metrics, and Measurement Strategies (2007), available at http://www.nsf.gov/statistics/nsf07306/pdf/nsf07306.pdf (concluding that much further research will be necessary to develop reliable innovation metrics).

23. See Lea Bishop Shaver, Defining and Measuring A2K: A Blueprint for an Index of Access to Knowledge, 4 I/S: J.L. \& POL'Y FOR INFO. SoC'Y 235, 264-65 (2008) (noting that rates of patent applications and grants reveal more about the ease and advantages of obtaining a patent, rather than accurately reflecting underlying rates of innovation).

24. See id. (suggesting that researchers focus on "high-value innovation" or narrow the focus of their study to one field rather than attempt to measure innovation across an entire society).

25. The empirical "case study" has no necessary relationship with the "case method" widely used in legal research and education. Literature on case studies as an empirical research methodology has been careful to distinguish its subject from the quite different use of cases as a teaching tool in law and business. See, e.g., Robert K. Yin, Case Study Research: Design and Methods 4-5 (4th ed. 2009) (describing a "teaching case" as one designed to establish a framework for discussion and debate among students and noting that the focus on his work is on the use of case studies as a research method). In contrast to the case method, the case study need not take a particular legal dispute or judicial opinion as its focus of inquiry. Of course, the "case" that is the object of empirical study might be a legal case, such as the Supreme Court's hearing of the Incandescent Lamp Case, 159 U.S. 465 (1895). But the "case" might also be a patent (such as Edison's '898 Patent), a technology (the light bulb), a patentee (Thomas Edison), a firm (General Electric), or a sector (the early electrical industry). Any specific, complex, functioning thing may be a "case" for study. See Robert E. STAKE, The ART of Case Study Research 2 (1995) [hereinafter Stake, Case Study RESEARCH]. My interest in understanding how patent law influences technological innovation led me to define my case around one technology-the early light bulb. Many different legal disputes, patents, patentees, and firms influence innovation in any particular field of technology. Therefore, focusing on any one particular opinion, patent, inventor, or company would likely narrow the inquiry too much and miss essential aspects of the larger innovation dynamics. A concrete technology (such as the light bulb or the smartphone) appears to be the simplest unit of investigation that allows us to seek answers 
researcher follows the path of that one subject to see where it leads and attempts to interpret its lessons. ${ }^{26}$ A leading articulation of the case study methodology in the social sciences proposes that "case studies are the preferred method when (a) 'how' or 'why' questions are being posed, (b) the investigator has little control over events, and (c) the focus is on a contemporary phenomenon within a real-life context." 27 These three conditions accurately capture the challenges associated with asking how patent law impacts technological innovation.

To be sure, a case study of any one technology has only limited utility for answering our larger questions about innovation. The dynamics of the particular technology selected may not be representative of all sectors or even of the general trend. Multiple data points are needed. It should also be acknowledged that case studies are fundamentally acts of interpretation. $^{28}$ To guard against investigator bias, these interpretations should be subject to peer review, public debate,

to questions about technological innovation and diffusion, without hiding the complex operations of patent law in the real world.

26. Within the substantial social scientific literature employing and commenting on case study methodology, some researchers prefer case studies because of normative commitments that achieving objective, accurate explanation of complex social phenomena is unattainable or undesirable. From these researchers' point of view, there is no "truth" in social science, only "interpretation." See Robert E. Stake, Case Studies, in THE SAGE HANDBOOK OF Qualitative Research 435, 439 (Norman K. Denzin \& Donna S. Lincoln eds., $2 d$ ed. 2000) [hereinafter Stake, QUALITATIVE RESEARCH] (describing some of the criticisms of case study research regarding their value to generalizability). This is not my point of view, nor is it my motivation for adopting this methodology. Quite to the contrary, the present study assumes that there is a correct answer to the question, "Does patent protection promote technological innovation?" and that social science can help us find that correct answer. Of course, the correct answer is unlikely to be a simple "yes" or "no." Rather, the accurate answer to this question is likely to be complex, to be filled with caveats, and to inevitably have some margin of uncertainty. The correct answer is likely to be: "Under certain circumstances, yes, patent protection does appear to promote innovation; and under other circumstances, no, patent protection appears to be counterproductive." Careful case studies can help illuminate these complex dynamics and help to form provisional answers, which may in turn be further tested and verified through quantitative analysis.

27. YIN, supra note 25, at 13.

28. See, e.g., StAKe, CASE Study Research, supra note 25, at 8 ("According to one highly respected writer on qualitative studies, Fred Erickson, the most distinctive characteristic of qualitative inquiry is its emphasis on interpretation.”). 
and independent studies of other cases, a phenomenon referred to in the case study literature as "triangulation." 29 Over time, however, the collective work of many scholars may build a robust body of case studies, which could provide a strong empirical basis to support or call into question key predictions and assumptions about the impact of patents on innovation. Even before this critical mass is reached, individual case studies can offer a helpful reality check on our theoretical models of how patent incentives work. Do theoretical predictions that seem to make sense in the abstract actually fit with what can be observed in the historical record? Or is there a significant gap between theory and fact, at least in the particular cases available to date?

The present work builds upon a body of empirical case studies that have already been developed by patent scholars looking at a number of modern technologies. For example, Lisa Ouellette has examined the disclosure function of patents in spreading scientific knowledge through the nanotechnology sector. ${ }^{30}$ Graham, Merges, Samuelson, and Sichelman have drawn findings about the role of patents in assisting startups, drawing on surveys of more than one thousand high-tech entrepreneurs in sectors ranging from biotechnology to software. ${ }^{31}$ Samuelson and Scotchmer have examined the economic impact of reverse engineering in the semi-conductor and software industries. ${ }^{32}$ Health economist Heidi Williams has used interviews and statistical analysis to document a negative impact

29. See id. at 111-15 (describing the triangulation protocols to "increase credence in the interpretation" and "to demonstrate commonality of an assertion").

30. See, e.g., Ouellette, supra note 17, at 552-71 (drawing on a survey of more than 200 nanotechnology researchers and case studies of selected nanotechnology patents to evaluate the impact of patents on scientific disclosure).

31. See Stuart J. H. Graham et al., High Technology Entrepreneurs and the Patent System: Results of the 2008 Berkeley Patent Survey, 24 Berkeley TeCH. L.J. 1255, 1255 (2009) ("We offer description and analysis of the 2008 Berkeley Patent Survey-the first comprehensive survey of patenting and entrepreneurship in the United States-summarizing the responses of 1,332 early-stage technology companies founded since 1998.").

32. See Pamela Samuelson \& Suzanne Scotchmer, The Law and Economics of Reverse Engineering, 111 YALE L.J. 1575, 1595-1626 (2002) (describing the results of the authors' study of the economic impact of reverse engineering in the semi-conductor and software industries). 
on downstream innovation for gene sequences covered by intellectual property. ${ }^{33}$ Fiona Murray and colleagues documented a similar negative impact in a comparison of laboratory mouse varieties subject to differing intellectual property restrictions. ${ }^{34}$ The above case studies each have a quantitative component, focusing on a particular set of data to answer particular questions about their cases. These studies illustrate the point that the empirical case study need not be purely qualitative.

A more recent trend in patent scholarship is to explore historical, as well as current, case studies. ${ }^{35}$ Thus, Gerard Magliocca has harvested lessons from the behavior of patent

33. Heidi Williams, Intellectual Property Rights and Innovation: Evidence from the Human Genome (Nat'l Bureau of Econ. Research, Working Paper No. 16213, 2011), available at http://www.law.nyu.edu/academics/colloquia/ innovationpolicy/ECM_PRO_070944; see also Rochelle C. Dreyfuss \& James P. Evans, From Bilski Back to Benson: Preemption, Inventing Around, and the Case of Genetic Diagnostics, 63 STAN. L. REV. 1349, 1365-70 (2011) (surveying empirical research on the effect of gene patents on medical innovation and drawing lessons for the patentability of genetic correlations).

34. See Fiona Murray et al., Of Mice and Academics: Examining the Effect of Openness on Innovation 4-5 (Nat'l Bureau of Econ. Research, Working Paper No. 14,819, 2009), available at http://www.nber.org/papers/w14819 (determining that research using mice species subject to greater intellectual property restrictions resulted in less "downstream" innovation than research using lessrestricted species).

35. There is also a larger body of historical work on patent law not employing the case study approach. See generally, e.g., B. Zorina Khan, The DEMOCRATIZATION OF INVENTION: PATENTS AND COPYRIGHTS IN AMERICAN ECONOMIC DEVELOPMENT, 1790-1920 (2005) (providing a historical overview of the development of patent and copyright law in America and its impact on economic development); CHRISTINE MACLEOD, INVENTING THE INDUSTRIAL Revolution: The English Patent System, 1600-1800 (1988) (examining trends in patenting and innovation as well as offering an intellectual history of the concept of invention in this time period); Catherine L. Fisk, Removing the 'Fuel of Interest' from the 'Fire of Genius': Law and the Employee-Inventor, 1830-1930, 65 U. CHI. L. REV. 1127 (1998) (examining the development of law respecting ownership of employee inventions during the 19th and 20th centuries in America); Moser, supra note 21 (using exhibition data to examine the impact of patent laws on innovation); Brad Sherman \& Leanne Wiseman, Fair Copy: Protecting Access to Scientific Information in Post-War Britain, 73 Mod. L. REv. 240 (2010) (discussing the impact of library copying provisions on the development of copyright law in post-war Great Britain); Kara Swanson, The Emergence of the Professional Patent Practitioner, 50 TECH. \& Culture 519 (2009) (tracing the historical roots of the modern patent bar); Steven Wilf, The Making of the Post-War Paradigm in American Intellectual Property Law, 31 COLUM. J.L. \& ARTS 139 (2008) (reviewing the expansion and development of the scope of intellectual property law in America since World War II). 
trolls with regard to nineteenth century agricultural machinery. ${ }^{36}$ Adam Mossoff has delved into patent thickets surrounding the early sewing machine industry. ${ }^{37}$ Kara Swanson uncovered the hidden dimensions of "the corset case" to offer a gendered perspective on patent law. ${ }^{38}$ And Christopher Beauchamp picks up the telephone as an object of cultural and legal disputes over inventorship. ${ }^{39}$

So far, historical scholars have not typically focused their attention on the innovation hypothesis, and innovation scholars have not generally favored historical case studies. ${ }^{40}$ Yet historical case studies may be critical to testing patent law's innovation hypothesis. The unique advantage of a historical case study is that the passing of time allows researchers to observe both shortterm and long-term results. This is crucial because the full impact of patent protection plays out over several decades. In the near term, incentives are perceived, a technology is developed, patents are issued, and products come to market. In the longer term, the new industry matures, litigation ensues, the firstgeneration patents expire, and second-generation innovation takes place. When studying cutting-edge technological sectors, our analysis is necessarily limited to the near term; the longerterm effects remain in the future, out of sight. This shortened horizon may introduce a systematic blind spot in our

36. Gerard N. Magliocca, Blackberries and Barnyards: Patent Trolls and the Perils of Innovation, 82 Notre Dame L. Rev. 1809, 1808-14 (2007).

37. Adam Mossoff, The Rise and Fall of the First American Patent Thicket: The Sewing Machine War of the 1850s, 53 ARIZ. L. REV. 165, 166-70 (2011).

38. Kara W. Swanson, Getting a Grip on the Corset: Gender, Sexuality, and Patent Law, 23 YAlE J.L. \& Feminism 57, 59-62 (2011).

39. Christopher Beauchamp, Who Invented the Telephone?: Lawyers, Patents, and the Judgments of History, 51 TECH. \& Culture 854, 855-66, 87778 (2010) [hereinafter Beauchamp, Who Invented the Telephone] (examining how patent law influenced the legal and cultural notions of who invented the telephone); see also Christopher Beauchamp, The Telephone Patents: Intellectual Property, Business, and the Law in the United States and Britain, 1876-1900, 9 ENTERPRISE \& SOC'Y 591 (2008) (using a case study of the early telephone industry in the United States and Great Britain to explore interactions between business strategies and national legal regimes).

40. Indeed, historical inquiry comes with challenges for the researcher interested in assessing the impact of patent law on innovation. Quantitative data may not have been recorded and might be impossible to gather now. Participant observation and interviewing are similarly unavailable as methodologies. 
understanding of patent law's true impact. The benefits of patent protection are visible immediately in the form of enhanced research and development spending, cutting-edge technologies, and new products on market. The long-term costs to competition, access, and next-generation innovation may take place later, out of sight. ${ }^{41}$

Taking a historic case study such as the light bulb allows us to examine the impact of patent law in the fullness of time-not just at the initial stage of research and development, but throughout the term of protection and past the expiration of firstgeneration patents. This greater perspective can allow researchers to observe long-term dynamics that would have remained hidden in the future when studying a more current technology. In the case of the light bulb, these long-term dynamics included massive litigation, ${ }^{42}$ the consolidation of a previously competitive industry, ${ }^{43}$ and a half-century lull between when incandescent-light technology was first patented and when it finally became widely accessible to the American public. ${ }^{44}$ Perhaps it should come as no surprise, then, that patent scholars centrally concerned with the innovation problem have heavily relied on the very limited historical research already at hand. ${ }^{45}$

41. See Bernstein, supra note 16, at 2311 (distinguishing the first step of innovation from the second step of diffusion and concluding that intellectual property law has been insufficiently concerned with the latter).

42. See, e.g., Harold C. Passer, The Electrical Manufacturers 18751900: A Study in Competition, Entrepreneurship, Technical Change, and ECONOMIC GRowTh 151-55 (1953) [hereinafter PAsser, The EleCtrical MANUFACTURERS] (describing the litigation that ensued surrounding the patenting of the light bulb).

43. See id. at 155-62 (describing the consolidation of the incandescent lamp industry following the upholding of Edison's light bulb patent).

44. See generally David E. Nye, Electrifying America: Social Meanings OF A NeW TEChNOLOGY, 1880-1940 (1992) (tracing the history of electricity's spread across America from its initial development in the early 1880s to its broad spread to ordinary Americans only in the 1930s and 1940s).

45. See, e.g., BESSEN \& MEURER, supra note 15 (discussing patents as a form of property right and concluding that patents fail as property in rewarding innovators and encouraging investment in innovation); BOLDRIN \& LEVINE, supra note 15 (analyzing the impact of intellectual monopolies created through patents and copyrights on the economic motivations for innovation); Mark A. Lemley, The Myth of the Sole Inventor, 110 MicH. L. REV. 709 (2012) [hereinafter Lemley, Sole Inventor] (examining the problem of simultaneous or near-simultaneous invention as it relates to patent law theory). 
History remains the best evidence available to us, in a world where controlled experiments are impossible. This promising body of evidence deserves more careful and extensive investigation.

\section{Law and the Light Bulb}

Many different technologies might have been the focus of an attempt to historically examine the innovation hypothesis. Why choose the light bulb? Robert E. Stake has distinguished three approaches to case study research: "intrinsic, instrumental, and collective." ${ }^{46}$ First, a researcher may choose to undertake a case study for intrinsic interest: not to understand a general phenomenon or build theory, but because the case itself is of inherent interest. ${ }^{47}$ Alternatively, a case may be explored with the primary goal of gaining an understanding of larger questions removed from the particular instance-the instrumental case study. ${ }^{48}$ My aim in undertaking this case study is decidedly instrumental. My research is driven by the desire to understand how patent law impacts technological innovation and diffusion. Many different technologies could have served that instrumental purpose; the light bulb offered simply one convenient starting point. In the future, several thoughtfully selected inventions might be explored through a collective case study. ${ }^{49}$

For many Americans, however, the case of Thomas Edison and the light bulb holds substantial intrinsic interest. People are interested in knowing more about the invention of the light bulb, for its own sake. Choosing this particular case thus offered me a vehicle to explore the innovation hypothesis, with the hope of finding a wider audience. A second advantage of the enduring intrinsic interest in the light bulb and Thomas Edison is that a

46. Stake, QuALITATIVE RESEARCH, supra note 26, at 438.

47. See id. at 437 (noting that the case is undertaken not "because the case represents other cases or because it illustrates a particular trait or problem, but because, in all its particularly and ordinariness, [the] case itself is of interest").

48. See id. ("The case is of secondary interest, it plays a supportive role, and it facilitates our understanding of something else.").

49. See id. (defining the collective case study as an instrumental study extended to several cases, which are selected as a sample to be representative of a broader class of phenomena the researcher wants to understand). 
substantial body of scholarship already exists on this case. This Article draws significantly on that existing scholarship to look for answers to a previously neglected research question. The availability of a wealth of primary and secondary materials on this case also means that researchers who share my interest in the innovation hypothesis have access to the same resources. Others may interpret these materials independently, critique my conclusions, and offer alternative explanations: such "triangulation" is an important check on case study work that seeks to answer an empirical question.

Discussion of Edison's work seems an almost inescapable element of any treatise on innovation. ${ }^{50}$ Yet the Great Inventor has so far attracted only a little attention from legal scholars. ${ }^{51}$ The Supreme Court's opinion in the Incandescent Lamp Patent case $^{52}$ is familiar to many patent attorneys, students, and scholars. It is excerpted in several patent casebooks and makes regular appearances in law review footnotes. ${ }^{53}$ Yet the case's

50. See, e.g., Harold Evans with Gail Buckland \& David Lefer, They Made America 151-71 (2004); Jonathan S. Feinstein, The Nature of Creative Development 565 (2006); Andrew Hargadon, How Breakthroughs Happen: The Surprising Truth About How Companies Innovate 249 (2003); Thomas P. Hughes, American Genesis: A Century of Invention and Technological Enthusiasm 517 (2004); Inventive Minds: Creativity in Technology 345 (Robert J. Weber \& David N. Perkins eds., 1992); RoberT W. WeisberG, Creativity: Understanding InNovation in Problem Solving, Science, InVEntion, AND THE ARTS 261-75 (2006); John Ziman, TechnOlOGical INNOVATION AS AN EVOLUTIONARY PROCESS 356 (2000).

51. For the exception that proves the rule, see Barak Y. Orbach, Prizefighting and the Birth of Movie Censorship, 21 Yale J.L. \& Human. 251, 251 (2009) (examining extensively Edison's role in adopting self-regulation as a mode of content censorship in the early motion picture industry). Orbach's interest was censorship and freedom of expression, yet his article's insight into Edison's business approach to motion picture technology is interesting from an intellectual property perspective as well. For instance, Orbach traces Edison's tendency to publicly exaggerate the progress of an invention and his inability to accurately predict the profitability of a technology at the time of its invention. See id. at 275-76 (recalling that Edison often used the press to promote uncompleted inventions without foresight into the financial benefits of such publicity). Edison also receives several paragraphs of attention in recent works by Mark Lemley and Brian Love; these works are discussed in detail in Part III of this Article.

52. Consol. Elec. Light Co. v. McKeesport Light Co., 159 U.S. 465 (1895).

53. The case quickly became known by the subject matter of the patent, rather than the parties' names. See, e.g., Walter Malins Rose, Notes on the United States Reports: A Brief Chronological Digest of All Points 
historical context, the litigation's implications for the electrification of America, and the case's potential larger lessons for innovation policy remain only dimly unappreciated. Indeed, the case name itself is a misnomer. There is no single patent corresponding to the incandescent lamp. Thomas Edison himself took out more than 100 patents on technical components of the incandescent lamp; ${ }^{54}$ his assistants and competitors also held many light bulb patents. Indeed, the patent at the center of the Supreme Court case was not Edison's but that of a rival. More often, we invoke Thomas Edison and his light bulb in passingtreating Edison as an icon, rather than as a subject of inquiry. ${ }^{55}$

Determined in the Decisions of The Supreme Court 776 (1901) (referring to the case by the name of "Incandescent Lamp Patent" and summarizing the holding as "the "[p]atent is void, where application is so vague that independent experimentation is necessary to construe it"); Dmitry Karshtedt, Limits on Hard-to-Reproduce Inventions: Process Elements and Biotechnology's Compliance with the Enablement Requirement, 3 HASTINGS ScI. \& TECH. L.J. 109, 138 (2011) (citing "the venerable Incandescent Lamp Patent case" as indicative of the genus-species rule of patent claiming); Mark A. Lemley, The Economics of Improvement in Intellectual Property Law, 75 TEx. L. REV. 989, 1002 (1997) [hereinafter Lemley, Economics of Improvement] (referring to the Incandescent Lamp Patent case as "a celebrated case" illustrating the principle that patent claim scope should be limited to embodiments actually enabled by the disclosure); Joshua D. Sarnoff, The Historic and Modern Doctrines of Equivalents and Claiming the Future, Part II (1870-1952), 87 J. PAT. \& TRADEMARK OFF. SOC'Y 441, 446 nn.121-27 (2005) (crediting the case with establishing the modern standard for enablement of claim scope, laying to rest earlier doctrine on pioneering patents).

54. See Israel, Claim the Earth, supra note 2.

55. See, e.g., Bernstein, supra note 16, at 2258 ("We adore genius and admire creators. We celebrate the achievements of Thomas Edison, and the extraordinary talent of Wolfgang Amadeus Mozart."); John S. Leibovitz, Inventing a Nonexclusive Patent System, 111 YALE L.J. 2251, 2251-53 (2002) (using a slightly fictionalized account of the Edison-Swan invention race as a "paradigmatic patent parable" to illustrate the drawbacks of a winner-take-all approach to patent rights); Corey McCaffrey, The Virtues of Virtual Marking in Patent Reform, 105 Nw. U. L. REV. 367, 367 (2011) ("The world is full of reminders that we are surrounded by inventions. When we see a light bulb, we remember Thomas Edison."); Michael J. Meurer \& Katherine J. Strandburg, Patent Carrots and Sticks: A Model of Nonobviousness, 12 LEWIS \& ClaRK L. REV. 547, 551-52 nn.12-15 (2008) (using Edison's light bulb as a familiar invention to illustrate the argument that higher nonobviousness standards push inventors to pursue more ambitious projects); see also Lemley, Sole Inventor, supra note 45, at 710 ("Any elementary-school student can recite a number of canonical American invention stories. Thomas Edison invented the light bulb from his famous home laboratory in Menlo Park, New Jersey."). Lemley's article does not end with the icon, however, but goes on to explore Edison's story in 
This Article seeks to go further, examining the invention, patenting, marketing, and litigation of the incandescent light bulb through the close lens of patent racing theory.

Before beginning this deeper inquiry, however, a brief introduction is in order. Many of us were taught as children that Thomas Alva Edison invented the light bulb. ${ }^{56}$ The full story is more complicated. A primitive light bulb had first been demonstrated more than seventy years before Edison's work began. ${ }^{57}$ In the intervening decades, crucial improvements in vacuum technology and electricity generation were developed that made electric light a newly promising technology. ${ }^{58}$ Beginning in 1878, Edison led a team of engineers who worked together to produce one of the first commercially practical systems of interior lighting. ${ }^{59}$ This team, however, had serious competition in the laboratory and the marketplace. ${ }^{60}$ The competition was so intense, in fact, that for many years after

greater depth, calling into question the iconic image. See id. at 722-23 ("It seems clear, however, that Edison did not 'invent' the lightbulb in any meaningful sense."). Lemley also uses the Incandescent Lamp Patent case as an illustration of the doctrine of enablement in the context of follow-on innovation. See Lemley, Economics of Improvement, supra note 53, at 1002-03 (discussing the court's decision to invalidate Sawyer and Mann's patent infringement claim against Edison on the grounds that Sawyer and Mann's patent for the use of any vegetable fiber as a filament did not preclude Edison from making further investigation using bamboo).

56. A number of works aimed at children present Thomas Edison as an archetype of the heroic inventor See, e.g., LAURIE CARLSON, THOMAS EDISON For Kids: His Life and Ideas: 21 Activities (2006); Inez Nellie McFee, The Story of Thomas A. Edison (1922); William H. MEAdOWCROFT With AUtobiographical Note By Mr. Edison, The Boy's Life of Edison (1911); Francis RolT-WheEler, Thomas Alva Edison (1915).

57. See BRIGHT, supra note 2, at 36 ("One of the first demonstrations of electrically induced incandescence was made in $1802 \ldots$...).

58. See id. at 38-42 (discussing the contribution energy advancements and vacuum developments had on the ultimate success of incandescent lighting).

59. See Robert Friedel \& Paul Israel with Bernard S. Finn, Edison's ELECTRIC Light: BIOGRAPHY OF AN INVENTION, 4-5 (1986) [hereinafter FRIEDEL \& ISRAEL, ELECTRIC LIGHT].

60. At the exhibitions of the International Electrical Congress in Paris in 1881-held after Edison had filed several patents in the field but before he had his first paying customers-incandescent lamps were displayed by Swan, LaneFox, Maxim, and Edison. Thomas P. Hughes, Networks of Power: ELECTRIFICATION IN WESTERN SOCIETY, 1880-1930, at 50 (1983) [hereinafter Hughes, Networks of Power]. 
light bulbs began to be widely manufactured and sold, it remained unclear who had won. Even today, British schoolchildren are taught that Joseph Swan, not Thomas Edison, won the race to invent the light bulb. ${ }^{61}$ Once electric light was ready for commercialization, many companies competed with Edison's in the marketplace. ${ }^{62}$ Compared to his rivals, however, Edison was particularly successful in litigating his portfolio of patents related to electric light technology. Edison leveraged his patent portfolio and courtroom successes to obtain mergers or market sharing agreements with most of his competition. ${ }^{63} \mathrm{~A}$ fifteen-year litigation campaign advancing claims based on a number of patents produced a stunning consolidation of a previously competitive market for light bulb manufacture. ${ }^{64} \mathrm{By}$ 1910, General Electric-the successor to Edison's electric light companies-would control $97 \%$ of all light bulbs sold in the U.S. market. ${ }^{65}$ The remainder of this Article examines both the early patent race and the later patent war in greater detail.

\section{Dynamics of Inventive Races}

One contribution historical case studies can make is to test existing theoretical models of patents' roles in incentivizing innovation. Part III of this Article uses the case study of the light

61. This version of history is reflected in the Wikipedia entry for Joseph Swan. See Joseph Swan, WIKIPEDIA (Sept. 12, 2012, 4:18 PM), http://en.wikipedia.org/wiki/Joseph_Swan (last visited Nov. 14, 2012) ("He is most famous for inventing an incandescent light bulb before its independent invention by the American Thomas Edison.") (on file with the Washington and Lee Law Review); see also Kenneth R. Swan, K.C., Sir Joseph Swan 15-39 (1946) (denouncing at the outset "the somewhat pretentious and all-embracing claims which have from time to time been advanced on Edison's behalf" and providing a detailed account of Swan's own claim to inventorship of the incandescent light bulb).

62. See BRIGHT, supra note 2, at 73 tbl.X (listing the "principal pioneer manufacturers of carbon-filament lamps in the United States").

63. See id. at 87-101 (illustrating Edison's use of his patent to bring injunctions against competitors, forcing many of them to close down or consolidate their businesses).

64. See id. (describing the "corporate purchases, consolidations, and regulations," mostly triggered by Edison's legislation tactics, that ultimately resulted in two companies controlling the electrical-goods industry).

65. Id. at $147-48$. 
bulb to test, critique, and refine one theory of "patent racing," which has been offered as one account of how patent protection may incentivize faster innovation. ${ }^{66}$ As articulated by Mark Lemley, patent racing theory centers on an underappreciated fact that proves problematic for other theories of patent-motivated innovation: most inventions are not breakthroughs at all, but ordinary engineering work that achieved its goal just a short time before the rest of the competition. ${ }^{67}$

In using the light bulb case study to test this theory, this Article draws upon a vast secondary literature describing the development of incandescent light. These historical accounts, however, predate patent racing theory, tend to discuss patents and patent law only tangentially, and are generally authored by writers more interested in Thomas Edison as a personality than in theoretical questions of innovation policy. The process of sifting through this literature is thus one of searching for needles in a haystack-finding those snippets of relevant information here and there in the corpus, historical asides that now enjoy a second life as data points completely unintended by their original documenters. In all cases, I have made a point to critically question whether the original author's account of the historical "facts" should be treated as reliable or not. As much as possible, this account relies only on data that can be confirmed through reference to more than one source.

Held up to the empirical light of Edison's bulb, Lemley's patent racing model proves to have substantial merit as a descriptive account. The racing metaphor captures a significant,

66. For a fuller picture of variations on the theory of patent racing and related models offered to explain how patents incentivize faster innovation, see John F. Duffy, Rethinking the Prospect Theory of Patents, 71 U. CHI. L. REV. 439, 440-47 (2004) ("[T] he race to claim patent rights becomes a race to diminish the patentee's rents by dedicating the invention to the public sooner."); Mark F. Grady \& Jay I. Alexander, Patent Law \& Rent Dissipation, 78 VA. L. REv. 305, 305-10 (1992) (identifying that the case law suggests that "patent protection applies only to inventions that signal large possibilities for improvement relative to the rent that a patent gives to the inventor") (emphasis omitted); Edmund W. Kitch, The Nature and Function of the Patent System, 20 J.L. \& ECON. 265, 265-67 (1977) (arguing that the patent system increases the output from resources used for technological innovation).

67. Lemley, Sole Inventor, supra note 45, at 710 (discrediting the "canonical story" of the individual inventor and suggesting that new technologies are oftentimes invented simultaneously by independent teams). 
and often overlooked, reality about the dynamics of innovation in the shadow of patent law and is helpful to understanding the development of the light bulb. In its present form, however, patent racing theory also has weaknesses. A closer look at the light bulb suggests that the better metaphor for understanding technological innovation may be neither a sprint nor a marathon but the board game Risk. Patent law does not provide clearly defined finish lines and criteria for judging winners, but rather a set of strategic resources for waging longer-term corporate battles. ${ }^{68}$ Ultimately, the experience of the light bulb leaves me less optimistic than Lemley that patent racing will fare any better as a normative justification for patent protection. Rather, a fuller understanding of the inventive race to control the light bulb should leave us even more skeptical of the innovation hypothesis.

\section{A. The Theory of Patent Racing}

In The Myth of the Sole Inventor, Mark Lemley explores the underappreciated dynamic of "simultaneous invention" and the problems it poses for the conventional economic justifications of patent protection. ${ }^{69}$ In case after case, Lemley's article illustrates that multiple inventors working on the same technological problem have arrived at the same solution at nearly the same time. ${ }^{70}$ The archetypal case here is the telephone: Alexander Graham Bell and Elisha Gray reportedly filed their competing

68. I am indebted to Robin Feldman at the UC Hastings College of the Law for the invitation to think of patent rights not as property claims in the traditional sense but as chips to be presented at the bargaining table when shares of ownership in a technology are eventually being resolved. I first encountered this presentation of patent law as an audience member when she gave a plenary presentation at the 2009 Intellectual Property Scholars Conference, and it greatly shaped my thinking about this project and the present Article. That presentation has now evolved into an excellent book, see Robin Feldman, Rethinking PATENT LAW (2012). My theory of patent warfare builds on Professor Feldman's view of patent strategy, although the metaphor I have chosen-war, rather than bargaining - reflects my view of the dynamic as less collaborative and more destructive than her own.

69. See Lemley, Sole Inventor, supra note 45, at 710-11 (arguing for a change in patent theory to accommodate the reality of simultaneous invention).

70. See id. at 735 (concluding, after a historical analysis, that it is "rare" for one inventor to develop a "wholly new product that no one else achieved at roughly the same time"). 
patent applications on the very same day. ${ }^{71}$ Simultaneous invention may also take a less obvious form, wherein a single product builds on incremental inventive contributions by so many different parties that it truly has no identifiable inventor. ${ }^{72}$

The overwhelming presence of simultaneous invention, Lemley argues, calls into question the dominant theoretical justifications for patent protection. ${ }^{73}$ If invention is the product of ordinary engineering work rather than extraordinary labors of genius, why do we award such an enormous prize to the party that achieved it first, if only by a few days? ${ }^{74}$ Lemley then proposes an alternative theory that might better justify patent protection, which begins from the reality of simultaneous invention, rather than from the myth of the sole inventor. ${ }^{75}$ This "patent racing" theory proposes that patent incentives accelerate innovation by increasing the stakes of the race to invent. ${ }^{76}$ All parties in the competition know that the first-place winner will take away a great prize, and the runner-up may be shut out completely. The enhanced competition these heightened stakes engender, Lemley suggests, may motivate greater investment of resources and thus accelerate the overall pace of innovation. ${ }^{77}$

The Myth of the Sole Inventor actually includes the light bulb among its historical examples of simultaneous invention, along the incremental model. ${ }^{78}$ Lemley correctly characterizes Edison's

71. See id. at 710, 720-22, 751 .

72. See id. at 714-15 (claiming that the incremental process of invention often leads to recognition of the "first person to make one significant step in the chain" and ignorance of "the developments that precede and follow it").

73. See id. at 737 ("The overwhelming presence of both independent invention and incremental contribution calls the basic incentive story into serious question.").

74. See id. at 752 ("If two or more putative investors invest that money in research and development in an effort to beat each other to the market, all but the first to invent will have wasted that money ....").

75. See id. at 750 (considering a patent system that recognizes the importance of cumulative innovation).

76. See id. at 753-54 (describing the benefits of a patent race, including the quicker progress of inventions, the possibility of a wide variety of approaches to solving a problem, and the improved quality of inventions that a deadline might encourage).

77. See id. at 753 ("[A] patent race should ... cause inventions to be made sooner than they otherwise would be ....").

78. Id. at $722-23$. 
inventive contribution as "an incremental one: one in a long chain of improvements." 79 Indeed, the contributions of Edison's research team took the form of a chain of improvements as well, with multiple patents filed on various aspects of the light bulb and its related technology as they were developed, ultimately building a robust patent portfolio surrounding electric light technology. A closer look at the development of the incandescent light bulb reveals strong support for some aspects of patent racing theory, and also suggests ways in which the framework requires complication and revision.

\section{B. Support for Patent Racing Theory}

First, the support: Thomas Edison was clearly in an inventive race. He had multiple contemporaneous rivals pursuing the exact same inventive goal: a commercially viable light bulb. ${ }^{80}$ According to Conot, at least thirty-one U.S. Patents in the area of incandescent light had already been granted and not yet expired. ${ }^{81}$ Edison thus began work on the incandescent light bulb in 1878, at a time when the field was already populated by competing inventors and prior patents. ${ }^{82}$ This competition continued after Edison entered the field, and multiple parties filed important patents in the United States and other jurisdictions. ${ }^{83}$ Edison ultimately began large-scale electric light

79. Id. at 723 .

80. See BRIGHT, supra note 2, at 44 (listing six other inventors working towards the development of incandescent electric lighting).

81. See Charles Bazerman, The Languages of Edison's Light 247 (1999) ("[I]n the 15 years before Edison was granted his first patent for incandescent light, 31 patents had already been granted in that area ...." (citing RoBERT E. CONOT, A STREAK OF LUCK 214 (1979))).

82. See FRIEDEL \& IsRAel, EleCtRIC Light, supra note 59, at 7-8 ("As early as 1841, Frederick De Moleyns, an Englishman, received a British patent for an incandescent lamp using both carbon and platinum. In 1845 an American, J.W. Starr, not only patented two forms of incandescent lamp ... but also traveled around England giving exhibitions and promoting his inventions."); see also William Sawyer, Elec. Lamp, U.S. Patent No. 235,459 (filed Sept. 20, 1880) (issued Dec. 14, 1880) (claiming a particular mechanism for fitting an electric lamp to a bracket).

83. See BAZERMAN, supra note 81 , at 247 ("[I]n the 15 years before Edison was granted his first patent for incandescent light, 31 patents had already been granted in that area...." (citing Robert E. CONOT, A STREAK OF LUCK 214 
service in New York City in September 1882.84 By that point, several other companies were also mass-producing electric light bulbs-and wielding their own patent portfolios. ${ }^{85}$

Offering further support for the validity of Lemley's metaphor, these parties also perceived themselves to be in a race. They were acutely self-conscious about their competition, sought out every available bit of information about the other teams' progress, and were generally quite concerned about who seemed to be ahead at any given moment. ${ }^{86}$ So were their

(1979))).

84. Edison's Electric Light, N.Y. Times, Sept. 5, 1882, at 8.

85. See, e.g., PASser, The EleCtrical MANufacturers, supra note 42 , at 191 ("Under [Hiram] Maxim, the [United States Electric Lighting Company] began production of incandescent-lighting plants for isolated use in 1880."). In August 1881, various light bulb manufacturers, including the Swan, Maxim, and Lane-Fox teams, in addition to Edison's, had demonstrated their wares at the Exposition Internationale de l'Electricité (Paris Exhibition). See Letter from Otto A. Moses, Edison Emp. (Aug. 26, 1881), in 6 The Papers of Thomas Alva Edison: Electrifying New YorK AND AbroAd 144-45 (Paul Israel et al. eds., 2007) [hereinafter PAPERS OF EDISON VoL. 6] (assuring the receiver of the letter that the Edison exhibit outshone all the rest). By 1882, several systems competed with Edison's. See Letter from Charles Mott to Arnold White (July 5, 1882), in PAPERS OF EDISON VOL. 6, supra, at 584-85 (referring to competing providers of incandescent light installations, including Siemens, Swan, "and others"); see also Letter from Frank J. Sprague, a member of Edison's research team, to Edward Johnson, another Edison employee (Sept. 21, 1882), in PAPERS OF EDISON VOL. 6, supra, at 655-57 ("Crompton informed me privately that the [Swan] Company were turning out 15,000 lamps a week, and I am inclined to believe him."); BAZERMAN, supra note 81, at 247-48 (discussing the patents wielded by other manufacturers).

86. This was true from the first months of Edison's work on incandescent light. See, e.g., Letter from E.W. Griffiths, counsel retained by Edison, to Thomas A. Edison (Oct. 30, 1878), in 4 The Papers of Thomas A. Edison: The WizARD OF MENLO PARK, 1878, at 657-58 (Paul Israel et al. eds., 1998) [hereinafter PAPERS OF EdISON Vol. 4] ("Mr. Lowrey directs me to send you a few hurried notes of a conversation had with Mr. Sawyer this morning." The enclosure then details particular technological accomplishments in which Sawyer claims to have anticipated Edison's team.) The very next day, Edison directed his attorney to conduct a thorough patent search. Letter from T.A. Edison to Lemuel Serrel (Oct. 31, 1878), in PAPERS OF EDISON VOL. 4, supra, at 658 ("Please make out a list of all US patents from the earliest ages to the present time on Electric light and send them for me [sic] Want them right off."). Edison's concern to keep apprised of his competition continued as the endeavor moved from the research stage to commercialization. A report from an Edison employee gives a sense of the competition research being conducted:

The Swan Company is pushing forward, and in this connection let me say that Edison must not abate the work on the lamp, Swan is 
investors. ${ }^{87}$ The progress made by the team of William Edward Sawyer and Albon Man posed particular problems for Edison. ${ }^{88}$ Between 1880 and 1883, the competitors were embroiled in a hard-fought priority battle at the U.S. patent office over which team had been first to achieve a key insight. ${ }^{89}$ The dispute went against Edison, and the issuance of the Sawyer and Man patent in 1885-along with Westinghouse's entry in the industry-set the stage for a decade of extensive and expensive litigation. ${ }^{90}$

Given the existence of other competitors, one very plausible interpretation of this history is that Edison's participation in this race merely accelerated the arrival of a commercially practical light bulb. Gas lighting was an extremely lucrative industry, ${ }^{91}$ and arc electric lighting was already finding commercial

making continual advance, and has recently commenced making lamps by a new process, which are the finest lamps I ever saw. They are not yet public, but Crompton, who is now one of the Swan Directors showed me one.... This new lamp is claimed to have 100 ohm resistance hot, and it can easily be increased, and to require but .6 of an empere, and 36 vol-tamperes, for 20 candle power. I think perhaps this is a little high, but is a wonderfully fine lamp, and I think can be made more cheaply than Edison's, and has fully as much life. He is making other lamps of 40 candle and has recently made lamps of 300 ordinary candle power.

Letter from Frank J. Sprague, in PAPERS OF EDISON Vol. 6, supra note 85, at 657. See also SWAN, supra note 61, at 19 (describing Swan's response to the growing publicity afforded to the competing systems of electric lighting).

87. See, e.g., FRIEDEL \& ISRAEL, supra note 59, at 26-29 (describing growing pressure from Edison's investors at the earliest stages of his research to demonstrate some advantage over existing teams of researchers)

88. See generally BAZERMAN, supra note 81, at 247-49 (describing Edison's practice of resolving conflicting patent claims over the incandescent light by combining forces with the businesses holding competing patents, but noting that this was not successful universally, and the Sawyer Man competition was particularly vexing).

89. See id. at 248-57 (detailing the patent interference proceedings and later litigation between the Edison and Sawyer-Man teams).

90. See id. at 248 (discussing the beginning of multiple infringement suits involving Edison and his competitors); infra Part IV.A (same); see also Israel, Claim the Earth, supra note 2, at 20 ("Edison and his company used their strong patent position to enforce licensing agreements with customers of both central and isolated stations and to attack competitors. By 1885, they were involved in nearly one hundred patent office proceedings and lawsuits involving electric lighting.").

91. BRIGHT, supra note 2, at 20 . 
application. ${ }^{92}$ The immense market potential of electric light in the household context was widely realized. For electric engineers of the day, the challenge of "subdividing the electric light"adapting it for domestic use-was an obvious goal, attracting significant attention and effort even before Edison entered the field. ${ }^{93}$ From the perspective of market incentives and of technological groundwork already laid, a commercially practical light bulb may have been a near inevitability.

Edison's participation, however, probably greatly increased the fervor of this race-at least between his 1878 entry and 1881, when Edison moved from Menlo Park to New York to oversee commercial introduction. Prior to Edison's entry, limited resources were being invested in pursuit of the incandescent light bulb. The leading American competition was the Sawyer-Man team. ${ }^{94}$ William Sawyer was a journalist turned inventor funded primarily by New York lawyer Albon Man, who organized the Electro-Dynamic Light Company for this purpose. ${ }^{95}$ The company had allocated $\$ 4,000$ to Sawyer's research between March and June 1878. ${ }^{96}$ Edison's talent for raising venture capital would produce a much bigger war chest: nearly $\$ 130,000$ in research funds were directed to his electric lighting work between 1878 and $1881 .{ }^{97}$ Edison's entry into the field not only attracted significant new investments to his own team, but also motivated increased investments to his competitors. In September 1878, the precise month that Edison threw his hat into the ring, the Sawyer-Man company set up a second workshop..$^{98}$

Indeed, Edison's entry may have been the defining event that truly kicked off the race for the light bulb as a serious one. When Edison filed his first light bulb patent in September 1878, he gave

92. See, e.g., id. at 32 ("Arc lighting was making commercial as well as technical progress in this country [the United States] by the time incandescent lighting appeared on the scene in 1880.").

93. Hughes, Networks of Power, supra note 60, at 31-32.

94. Paul IsRael, Edison: A Life Of Invention 188 (1998) [hereinafter ISRAEL, A LIFE OF INVENTION].

95. Id.

96. Id.

97. Id. Adjusted for GDP deflation, Edison's $\$ 130,000$ in research expenses from 1878 to 1881 translates to more than $\$ 2.5$ million in current dollars. Id.

98. $I d$. 
an interview to the New York Sun in which he claimed definitively-if not accurately-to have solved the problem of incandescent light. ${ }^{99}$ A brief excerpt serves to illustrate the effect:

Mr. Edison says that he has discovered how to make electricity a cheap and profitable substitute for illuminating gas. Many scientific men have worked assiduously in that direction, but with little success. ... It has been reserved for Mr. Edison to solve the difficult problem desired. This, he says, he has done within a few days... "I have obtained it through an entirely different process from which scientific men have ever sought to secure it. They have all been working in the same groove, and when it is known how I accomplished my object, everybody will wonder why they have never thought of it, it is so simple ...."100

A few days later, Edison began financial negotiations for investments. ${ }^{101}$ A letter privately assured one potential investor that "all serious difficulties have been overcome and there is every reason to believe that [Edison] has discovered the means of giving an electrical light suitable for every use at a vastly reduced cost as compared with the cost of gas."102

Edison thus claimed to not only be ahead of his competition in the inventive race for incandescent light, but to have already won. Stock prices in gas companies tumbled, indicating that at least some people took these claims seriously. ${ }^{103}$ More sophisticated investors, however, knew better than to take Edison's initial claims at face value. ${ }^{104}$ They suspected that the solution was not yet in hand and even doubted whether Edison

99. Edison's Newest Marvel, N.Y. Sun, Sept. 16, 1878, in Theresa M. Collins \& Lisa Gitelman, Thomas Edison and Modern America: A Brief HisTORY WITH DOCUMENTS 83-85 (2002).

100. Id. at 83 .

101. BAZERMAN, supra note 81 , at 10 ; FRIEDEL \& ISRAEL, supra note 59, at 14.

102. Letter from G.P. Lowrey, Edison's representative in investment negotiations, to Hamilton McKay Twombly, representative of potential investor William H. Vanderbilt (Oct. 1, 1878), in PAPERS OF EDISON VOL. 4, supra note 86, at 658 .

103. See FRIEDEL \& ISRAEL, supra note 59, at 23 ("[I]n early October the news from America caused a panic in gas shares in London, where Edison's reputation for wizardry was unequaled.").

104. See id. at 14 ("[T]he story was read by some of the Wall Street moneymen who had already learned to be wary of Edison's technical genius."). 
would ultimately be the first to achieve it. ${ }^{105}$ Indeed, the technique Edison claimed in U.S. Patent No. 214,636, "Improvement in Electric Lights," was ultimately unsuccessful. The line of research reflected in this first patent filing was discarded entirely and the design never made it into an actual product. ${ }^{106}$ Edison would not be able to publicly demonstrate a successful bulb-utilizing a different underlying technologyuntil more than a year later, at the end of December $1879 .{ }^{107}$

Although Edison's claims were premature, they could not be ignored. Lemley suggests that patents may increase the incentives in a race as both a carrot and a stick. From the carrot perspective, runners race because they believe that they will finish first and obtain a patent reward. ${ }^{108}$ From the stick perspective, runners are motivated to go faster because they fear that their competitors will win, obtaining patent rights that shut them out of a lucrative market. ${ }^{109}$ Looking at the race for the light bulb, the stick dynamic seems to be strongly in play. Edison's 1878 claims represented a threat that he would solve the problem of the light bulb in the near future. That threat seemed uniquely

105. Potential investors in Europe asked to see a working model of the invention, which Edison promised to send through his agent George Gourad. See Letter from Thomas A. Edison to Theodore Puskas (Oct. 5, 1878), in THERESA M. Collins \& Lisa Gitelman, Thomas Edison and Modern America: A Brief History with Documents, at 85-86 (2002) [hereinafter A BRIEF History]. Two days later, however, a telegram from Gouraud himself to Edison vainly pleaded for a demonstration or some helpful detail of the breakthrough that could be publicly shared to bolster confidence before panicked British investors moved to support a rival system. See Telegram from George Gourad to Thomas A. Edison (Oct. 7, 1878), in A BRIEF HisTORY, supra note 105, at 86. Edison cabled back advising Gourad to "let them go ahead," as he could not yet provide the requested proof. Id.; see also FRIEDEL \& IsRAEL, supra note 59, at 14 (describing the hesitancy of investors in financing Edison's new invention).

106. BAZERMAN, supra note 81 , at 186-89. Bazerman deftly provides a clear explanation of the technique claimed by Edison in this first patent, which even a non-engineer can understand, as well as reproducing the patent specification and claims, as issued. $I d$.

107. See e.g., $i d$, at 183-85; FRIEDEL \& IsRAEL, EleCtRIC LiGHT, supra note 59, at 111-14; ISRAEL, A LIFE OF INVENTION, supra note 94, at 187-88.

108. See Lemley, Sole Inventor, supra note 45, at 755 (describing the different motivations for inventors to move quickly in developing their invention).

109. See id. (describing the role a patent race can play as a "stick" by motivating inventors to move quickly to avoid "the risk of losing a race and being excluded from competition in that market"). 
credible coming from Edison because of his public reputation as an inventor and because of his obviously passionate commitment to this particular technological challenge. ${ }^{110}$

Edison's entry into the race on these terms helped to create an air of inevitability surrounding incandescent lighting. The perfection of the technology suddenly seemed close at hand. Investors scrambled to pick sides and stake claims in what now appeared poised to be an important new industry. ${ }^{111}$ Gas lighting companies stood to come out as losers no matter which team won the race. This made it all the more important for them to throw some of their great resources into backing a winning team in order to hedge their existing investments. The race was definitively on and gathering momentum. The key points of Lemley's theory - the prevalence of simultaneous invention, the role of patent protection in raising the stakes, and the power of competition to motivate increased investments in research and development-all find support in the race to perfect the light bulb.

\section{Problems for Patent Racing Theory}

Despite all this support in the historical record, Lemley's theory of patent racing has been vehemently disputed by business professor John Howells and his co-author, Ron D. Katznelson. ${ }^{112}$ These critics specifically take issue with Lemley's use of the light bulb as an example of incremental invention. ${ }^{113}$ They argue that Edison's contribution in fact "unlocked the field," that it cannot be placed on par with contributions by any other inventor, and

110. See FRIEDEL \& ISRAEL, supra note 59, at 29 (suggesting that initially, Edison's chief asset was self-confidence, largely shared by the world at large).

111. See id. at 14 (examining the various investors who decided to finance Edison's operation, including individuals associated with the telegraph and gas companies).

112. See John Howells \& Ron D. Katznelson, A Critique of Mark Lemley's "A Myth of the Sole Inventor" 4-5 (Sept. 15, 2011) (unpublished manuscript), available at http://bitly.com/Lemley-Critique (on file with author).

113. See id. (disputing Lemley's claim that Edison was not a sole inventor by highlighting the distinct strengths of Edison's invention in contrast with those of his competition). 
that Edison was deserving of a "pioneer" patent.114 My own examination of the light bulb case puts me on the side of Lemley rather than his critics. The central mistake made by Howells and Katznelson is to treat judicial opinions and patent claims as reliable evidence of who really did what. ${ }^{115}$ These legal documents emphatically assert that Edison's inventive contributions were without peer. Such assertions, however, should be treated with great skepticism. The historical claims about Edison's contributions, which Howells and Katznelson present as fact, are better understood as a deeply mythologized "narrative of invention" that Edison himself forged in preparation for litigation. ${ }^{116}$ The model of incremental innovation more accurately fits the true history of the light bulb's development.

Contrary to Howells and Katznelson's position, my concern with Lemley's patent racing theory is that the model may not go far enough to reflect the reality of incremental innovation. Lemley describes simultaneous invention as existing in two models. ${ }^{117}$ The first model is when two inventors are working on the same technology, and the contest is to see who will produce it first. ${ }^{118}$ Lemley offers the telephone as the archetype of a patent race: two inventors almost literally racing to the patent office door. ${ }^{119}$ But the second model is probably more common. This is when the process of invention is characterized by roughly

114. Id. at 6. The concept of a "pioneer patent" was popular in American patent doctrine at the late nineteenth and early twentieth centuries. Proponents argued that when an inventor had made a "pioneering" contribution to a new field of technology, he should be entitled to broad claims covering not only the specific embodiment they had produced but also later generations of the technology that others developed. For a critique of this doctrine-and argument as to its enduring relevance-see Brian J. Love, Interring the Pioneer Invention Doctrine, 90 N. CAROLINA L. REV. 379, 389 (2012).

115. See Howells \& Katznelson, supra note 112, at 4-7 (describing the reasons that Edison's patent for the incandescent light was superior to his competitors).

116. See generally Lea Shaver, Patents, Publicity, and the Myth of Invention (2012) (unpublished manuscript) [hereinafter Shaver, Myth of Invention] (on file with author).

117. See Lemley, Sole Inventor, supra note 45, at 731 (“[I]nventions . . are in fact generally the products either of simultaneous independent invention or of incremental development from multiple sources, or both.").

118. Id. at $712-15$.

119. Id. at $720-22$. 
contemporaneous contributions by so many different parties that it becomes impossible to declare any one true "father" of the technology. ${ }^{120}$ The race for the light bulb, at least, best fits this pattern of incremental innovation. ${ }^{121}$ Even in the case of the telephone, the narrative of the race to the patent office may be more a product of litigation stance than of the underlying reality of technological development. ${ }^{122}$

If the pattern of incremental innovation is indeed the prevailing one, as I suspect, we need a reconceptualization of racing theory that deemphasizes the patent office door as the finish line. Doing so, however, destabilizes the metaphor. Central to the concept of a race is the existence of a clearly defined finish line, at which point the winners and losers are declared based upon a simple and objective measure of performance. Indeed, the very purpose of the race as an athletic convention is to enable this objectivity by clearly defining the terms of the contest in advance. A political campaign also meets these two criteria of a traditional race: a clearly defined endpoint (election day) and an objective methodology for determining the winner (tabulating votes). Inventive races, however, may not conform to this model. The race for the light bulb, at least, lacked these two key characteristics. ${ }^{123}$

120. Id. at 715-16.

121. For a comprehensive account of innovations in electrical lighting between 1880 and 1890, well situated in their economic and political context, see generally HUGHES, NeTWORKS OF POWER, supra note 60.

122. See Beauchamp, Who Invented the Telephone, supra note 39, at 877 (highlighting the difficulty of "the question of where, on the continuum of conceptualization, experimentation, 'reduction to practice,' and commercialization, the invention of the telephone should be rightly marked").

123. The inventive race for the light bulb has one other similarity with political races, however: the dynamics of self-fulfilling prophecies. In a political campaign, contenders seek to create the perception that they are in the lead, in order to win over those potential supporters who simply want to throw in their lot with the likely winner. Edison thus cultivated the media and exaggerated his own progress to discourage investors from backing his rivals. See FRIEDEL \& ISRAEL, supra note 59, at 13 . Similar to a political campaign, impressions about which inventive team is ahead can translate into additional resources helpful for getting ahead, making such prophecies self-fulfilling. Mercifully, even the longest political campaign finds its end within eighteen months, and a victor is clearly anointed. Not so with an inventive race, in which it may take more than a decade for courts to declare the winner. 
Indeed, this particular race was so closely and fiercely contested that for many years-even years after light bulbs were widely being manufactured in the United States-there was no clear winner. Throughout the 1880s, multiple companies, each holding patent portfolios from different inventive teams, claimed strenuously that their champions had prevailed. ${ }^{124}$ Ultimately, these conflicting claims had to be settled by the law. ${ }^{125}$ In doing so, the patent office and the courts had to apply legal criteria that are infinitely more complex and subjective than those commonly used to judge athletic and political races. Courts also had to make this determination, not immediately after the relevant finish line, but many years later, upon an imperfect evidentiary record developed by deeply interested parties. In one crucial trial, for instance, Edison's attorneys persuaded the judge that William E. Sawyer had in fact never made the lamp claimed in the disputed patent. ${ }^{126}$ Because ten years had passed between the claimed experiments and the Incandescent Lamp Patent trial, Mr. Sawyer was no longer alive to testify personally as to the events.

Beyond mere problems of evidence, Robin Feldman argues persuasively that subjectivity and indeterminacy are inherent features of patent interpretation. ${ }^{127}$ In Feldman's words, "[p]atents cannot possibly delineate the boundary of an inventor's rights because those rights will be established in relation to products that have yet to be created at the time of the patent grant."128 Patent lawyers face the daunting task of choosing words to capture the essence of a technology that by definition

124. See, e.g., BAZERMAN, supra note 81, at 247-48 (describing the uncertain and overlapping claims of ownership over the light bulb technology and the increasingly competitive production of light bulbs based on these various patents).

125. See id. at 248-50 (describing the interference battle between Edison and the Sawyer-Man team at the patent office in 1881-1883 and later litigation); PAsser, The EleCtriCAl MANUfACtURERs, supra note 42, at 151-59 (describing the beginning of patent litigation over the incandescent lamp in 1885 and its continuation for many years); Consol. Elec. Light Co. v. McKeesport Light Co., 159 U.S. 465 (1895) (invalidating a Sawyer-Man patent under which any light bulb with a filament of carbonized vegetable matter would have been deemed infringing).

126. Consolidated Elec. Light Co. v. McKeesport Light Co., 40 F. 21, 28-29 (C.C.W.D. Pa. 1889), aff'd, 159 U.S. 465 (1895).

127. See generally Feldman, Rethinking Patent LaW, supra note 68.

128. Id. at 3 . 
has never before been described, in order to compare it in the future to other technologies that do not yet exist. ${ }^{129}$ "Taken together, this set of circumstances ensures that a patent could never grant a definitive and clearly bounded set of rights." 130 Feldman concludes that a patent must be understood not as a clear marking of the "metes and bounds" of one party's intellectual property, but rather as an invitation to bargain with others over the scope and value of the patent rights. ${ }^{131}$ In the end, "the extent of the rights cannot truly be known until the day that the patent expires." 132 Keeping Edison's experience in mind, we might also characterize this inherent uncertainty of patent claims as not just "an invitation to bargain," but also as an invitation to litigate.

Because of problems of evidence, indeterminate claim language, and shifting standards of legal interpretation, the nature of the competition in a patent race may be much less objective and meritocratic than the metaphor initially suggests. Are inventive races meaningfully similar to the 100-meter dash or a presidential primary? Or are they more like an Olympic gymnastics competition, in which the American and Soviet judges may arrive at wildly different conclusions? ${ }^{133}$ Whether we view the patent race as a fair and objective contest or not has great implications for the degree of confidence we place in the patent system to pick winners and losers, and therefore, to structure the proper incentives for technological innovation. Lemley's patent racing model lessens the power of the myth that inventions appear out of thin air, and would not have existed but for the contributions of the credited inventor, a misperception that too easily favors very strong patent rights. Without great caution, however, the patent racing model might replace an old myth with a new one: that of the patent race as a fair and clean contest. Patent law on the ground is not so neat and tidy.

129. Id.

130. Id.

131. Id.

132. Id. at 5 .

133. After all, American courts picked Thomas Edison, and British courts picked Joseph Swan. 
The patent racing model also carries a second risk: it tells only part of the story and leaves out what might be the most important part, from the perspective of innovation. Patent racing theory best describes the early stages of development of a new technology. In the latter stages of commercialization, improvement, and diffusion of that technology, the nature of the competition shifts very distinctively. ${ }^{134}$ This latter dynamic, which I term "patent warfare," can also be understood as a contest or game. But its nature is quite different from the patent race described by Lemley, and its implications for innovation are not nearly so positive. A look at what happens next in the story of the light bulb-after the technology was perfected enough for Edison and others to begin to commercialize it-will make this point crystal clear.

\section{Learning from the Light Bulb}

\section{A. From Patent Racing to Patent War}

In Part III, the early contest to develop and bring to market an incandescent light bulb was used to test the theory of patent racing. The history largely supports the theory of patent racing, albeit with skepticism as to any implication of a clear finish line. After the light bulb came to market, however, the dynamics of the competition among inventive teams shifted dramatically. Here, the more accurate metaphor is neither a sprint nor a marathon, but the strategic board game Risk. ${ }^{135}$ In this game, the board resembles a map of the world, with varying territories. In the early stages of the game, players amass tokens representing armies and position them strategically on the board to fortify their positions. Eventually, the game shifts into attack mode, as

134. I am indebted to Gaia Bernstein for highlighting an important distinction between innovation and diffusion of new technologies. See, e.g., Bernstein, supra note 16, at 2290-91 (distinguishing the innovation and diffusion stages of a technology's introduction and arguing that intellectual property law neglects the latter).

135. See Risk (game), WIKIPEDIA, (Sept. 14, 2012, 4:45 PM), https://en. wikipedia.org/wiki/Risk_(game) (last visited Nov. 14, 2012) (offering a full description of the game of Risk) (on file with the Washington and Lee Law Review). 
players vie to conquer each other's territories. Ultimately, one party pushes out all the competitors and achieves the goal of the game: world domination.

Similarly, industrial contenders may spend years amassing a patent portfolio and income streams that will eventually fund their litigation war chest. At a certain point, when one party thinks it is the right amount ahead, it begins to close in on its opponents. Both in Risk and in patent warfare, the strategic campaigner should begin by confronting its weakest competitors because those victories will be easiest. The victor may also amass strength by absorbing the assets-patent portfolio and market share-of the vanquished foe. Finally, the two strongest competitors confront each other, as the Edison and Westinghouse companies faced off in the litigation that reached the Supreme Court in the Incandescent Lamp Patent case.

To paraphrase the classical military theorist Clausewitz: Patent litigation is the continuation of business strategy by other means. ${ }^{136}$ Patent racing is helpful for understanding how patents impact innovation leading up to the patent filing. But the longterm impact of patent law on industrial competition requires a very different metaphor. Patents acquired in the racing stage become pawns in a battle to achieve market dominance and secure competitive position. Contrary to the metaphor of the race, it is not who is first to the patent office that wins, but who is last left standing at the end of litigation.

In the early days of the light bulb's commercial use, patents proliferated but did not pose a barrier to competition. Economic historian Harold C. Passer points out that Edison had a significant share of the market early on, but not anything like exclusive control. ${ }^{137}$ In Passer's words: "In the beginning, very little attention was paid to patents, and manufacturers could make the entire incandescent system. The dynamo could not be

136. See Carl Philipp GotTfried von Clausewitz, On War 87 (Michael Howard \& Peter Paret eds., trans., Princeton University Press 1976) ("War is ... a continuation of political activity by other means."). Carl Philipp Gottfried von Clausewitz was a Prussian General and writer in military theory. See id. at 3-25 (describing the background and history of Carl Philipp Gottfried von Clausewitz).

137. See Passer, The Electrical Manufacturers, supra note 42, at 206 ("Of the 250,000 [incandescent lights] in use in 1885, over 200,000 were Edison lights on Edison equipment.”). 
patented, and lamp patents were not respected."138 By 1890, however, Edison's market share had fallen to less than half. 139 Patent warfare was crucial to reversing that trend and securing Edison's control of the light-bulb market. In the first year of litigation, Edison's company was involved in nearly one hundred patent disputes, including administrative proceedings. ${ }^{140}$ Between 1885 and 1895, more than twenty major opinions were issued in U.S. cases disputing Edison's claims to control of the incandescent light bulb. ${ }^{141}$ By 1901, Edison's side had spent about $\$ 2,000,000$ on more than two-hundred lawsuits related to its lighting patents. ${ }^{142}$ The Sawyer-Man infringement suit against Edison alone generated more than 5,000 pages of documents, not including the patent application and interference stages. ${ }^{143}$ Nor was the litigation confined to the American shores. Foreign patents and litigation, especially in Great Britain and in

\footnotetext{
138. Id.

139. Id.

140. Israel, Claim the Earth, supra note 2, at 20.

141. See, e.g., Edison Elec. Light Co. v. Waring Elec. Co., 59 F. 358 (C.C.D. Conn. 1894) (granting preliminary injunction against infringement of Edison Patent No. 223,898), aff'd, 69 F. 645 (2d Cir. 1894) (per curiam); Edison Elec. Co. v. Boston Incandescent Lamp Co., 62 F. 397 (C.C.D. Mass. 1894) (granting preliminary injunction against infringement of Edison Patent No. 223,898); Edison Elec. Co. v. Bos. Incandescent Lamp Co., 62 F. 397 (C.C.D. Mass. 1894) (granting preliminary injunction against infringement of Edison Patent No. 223,898); Edison Elec. Light Co. v. Beacon Vacuum Pump \& Elec. Co., 54 F. 678 (C.C.D. Mass. 1893) (granting preliminary injunction against infringement of Edison Patent); Edison Elec. Light Co. v. Elec. Mfg. Co., 57 F. 616 (C.C.E.D. Wis. 1893) (upholding the validity of Edison Patent No. 223,898 and finding infringement), aff'd, 61 F. 834 (7th Cir. 1894); Edison Elec. Light Co. v. U.S. Elec. Lighting Co., 52 F. 300 (2d Cir. 1892) (upholding the validity of Edison Patent No. 223,898 and finding infringement), decree modified sub. nom. Edison Elec. Light Co. v. Sawyer-Man Elec. Lighting Co., 53 F. 592 (2d Cir. 1982); Edison Elec. Light Co. v. Westinghouse, 40 F. 666 (C.C.D.N.J. 1889) (upholding the validity of Edison Patent No. 264,642 and finding infringement); Consol. Elec. Light Co. v. McKeesport Light Co., 40 F. 21 (C.C.W.D. Pa. 1889) (invalidating Sawyer-Man Patent No. 317,676, erroneously referred to in the opinion as No. 317,076), aff'd, 159 U.S. 465 (1895). Paul Israel estimates Edison was involved in nearly 100 patent disputes involving electric light by 1885 . Israel, Claim the Earth, supra note 2, at 20.
}

142. BRIGHT, supra note 2, at 136-37.

143. See BAZERMAN, supra note 81, at 239-40 ("The conflict . . . moved to the courts, where it produced eight volumes of documents totaling more than 5000 pages."). 
Germany, formed an important part of Edison's transnational litigation strategy.

As companies in the field of incandescent light technology negotiated cross-licensing deals and takeovers, patents on many aspects of the electrical lighting system played important roles. ${ }^{144}$ But in U.S. litigation one of Edison's many patents on the light bulb would ultimately play the most important role. Issued on January 27, 1880, U.S. Patent No. 223,898 ('898 Patent) recognized Thomas Alva Edison's “improvement in electric lamps," including a claim on "[a]n electric lamp for giving light by incandescence, consisting of a filament of carbon of high resistance, made as described, and secured to metallic wires, as set forth." 145 The '898 Patent was just one among dozens of patents that Edison sought on the light bulb technology, and it was not initially clear that it would prove so central. ${ }^{146}$ Competitors in the industry strongly doubted the validity of its claims. ${ }^{147}$ That changed crucially when a Pennsylvania court, in the course of invalidating a rival patent held by Sawyer and Man, and in dicta, gave Edison's '898 Patent a new interpretation so broad as to render virtually every incandescent light bulb infringing. ${ }^{148}$ Subsequent litigation produced a stunning consolidation of the previously very competitive American electric industry. ${ }^{149}$ After the Supreme

144. See BRIGHT, supra note 2, at 86. See generally Israel, Claim the Earth, supra note 2.

145. Thomas Alva Edison, Elec. Lamp, U.S. Patent No. 223,898 (filed Nov. 11, 1879) (issued Jan. 27, 1880). The patent contains three additional independent claims, which are omitted here for the sake of brevity. Id.

146. See BAZERMAN, supra note 81, at 86-89 (explaining that, despite the large number of Edison patents, only the '898 Patent was deemed "crucial").

147. See Passer, The Electrical Manufacturers, supra note 42, at 15354.

148. See Consol. Elec. Light Co. v. McKeesport Light Co., 40 F. 21 (C.C.W.D. Pa. 1889), aff'd, 159 U.S. 465 (1895) (invalidating the Sawyer-Man Patent); Passer, The Electrical Manufacturers, supra note 42, at 155 ("The meaning of the decision seemed to be that the Edison patent could be the basis for an absolute monopoly of incandescent-lamp manufacture in the United States.”); see also BAZERMAN, supra note 81, at 250-57 (offering an insightful account of the McKeesport trial).

149. See BRIGHT, supra note 2, at 84-93; see also BAZERMAN, supra note 81, at 239-40 (explaining that, after the litigation with its industry competition, the Edison companies and their successor, General Electric, emerged as "the primary owner of light technology as the industry expanded"). 
Court's 1895 decision, all U.S. producers either purchased licenses from General Electric or merged with it. ${ }^{150}$

Passer's economic study documents the transformation of the light bulb market before and after the patent litigation. In the early years of the electrical industry, he writes:

Patents were not significant in either the product or the manufacturing process. In these conditions-a standardized product sold mainly to business firms, relatively free entry, many buyers, and more than fifteen sellers-the market closely approached the economist's concept of pure competition. The competition was almost entirely in prices, and these were driven down to cost by the additional supply from new firms. But these freely competitive conditions did not prevail for long. The year 1888 marked the end of pure competition in arc carbons, and 1896 [the year after The Incandescent Lamp Patent was decided] saw the termination of pure competition in incandescent lamps. ${ }^{151}$

By 1897, General Electric was the undisputed leader, and Westinghouse was its only serious rival. ${ }^{152}$ The two companies agreed to a truce in the form of patent cross-licensing and product pricing agreements. ${ }^{153}$ Smaller competitors were invited to join

150. See BRIGHT, supra note 2, at 136-37 (explaining that the combination of "patent victory, consolidations, and patent and marketing agreements" made Edison the indisputable leader of the domestic incandescent-lamp industry).

151. Passer, The Electrical Manufacturers, supra note 42, at 350. Passer details forces contributing to the demise of competition including both nonpatent and patent factors. Of the latter, he writes:

Patents also influenced competitive conditions. They were a prime cause of the numerous consolidations and mergers which finally resulted in only two full-line producers. Furthermore, patents permitted competition to take place on a system basis instead of with reference to single items of equipment. Manufacturers could refuse to allow the use of particular patented apparatus except as a part of a complete lighting or power system.

Id. at 352 .

152. See BRIGHT, supra note 2, at 144 ("In 1987 the General Electric Company was unquestionably the leader of the American electric-lamp industry. It had recently entered into a general cross-licensing arrangement with the Westinghouse Electric \& Manufacturing Company, its largest competitor . . ..”).

153. See id. at 12 ("A general patent-licensing arrangement between General Electric and Westinghouse in 1896 and subsequent specific licenses established a pattern in the lamp industry which was substantially maintained until 1945."); see also W. BERnARD CARLSON, InNovation AS A Social Process: EliHU Thomson AND the Rise of General Electric 271-301 (1991). 
the Incandescent Lamp Manufacturers Association, organized by General Electric. These members agreed to divide up the markets and avoid price competition. ${ }^{154}$ The result was that G.E. sold half of the bulbs in the U.S. market, and the smaller companies divided the other half. ${ }^{155}$ These smaller companies, dependent on G.E. patent licenses for their existence, put no downward pressure on prices and were discouraged from contributing their full potential to next-generation innovation. ${ }^{156}$ In Bright's words: "They gave only the appearance of competition." 157 Through incorporation, patent litigation, licensing deals, and eventually purchases of stock, by 1910, G.E. controlled $97 \%$ of the market. 158 Only then could Edison finally rest, his empire secure.

History remembers Edison as a workshop inventor, a tinkerer - an image established, in no small part, by Edison's own efforts. A more accurate historical portrait begins with recognizing Edison as an entrepreneur and empire builder. ${ }^{159}$

154. See BRIGHT, supra note 2, at 144 (explaining that General Electric organized the Incandescent Lamp Manufacturers Association, obtaining the cooperation of a large proportion of the industry, including six "formerly bitter rivals," who joined to avoid intense price competition).

155. See id. ("The members of the association agreed among themselves to fix lamp prices, both wholesale and retail, to divide business and customers, and to set terms of sale.").

156. See id. at 457. ("The role of the licensees was largely passive... add[ing] little to the vitality of the lamp industry; and they aided General Electric in retaining its hold over the industry. They did not provide any real downward pressure on prices. They gave only the appearance of competition.").

157. Id.

158. Id. at 147-48. An antitrust investigation subsequently found misconduct, but the remedies did not require the company to seriously change its business model. General Electric would continue to dominate the light bulb market for decades longer. See id. at 253-56.

159. In an unguarded moment, Edison's voice was captured on his own phonograph in an exchange suggesting Edison saw himself as a "hustler." Stross tells the story best:

One occasion when Edison cast off the expectations of others in his middle age was when he met Henry Stanley, of "Dr. Livingston, I presume" fame, and Stanley's wife, who had come to visit him at his laboratory in West Orange, N.J. Edison provided a demonstration of the phonograph, which Stanley had never heard before. Stanley asked, in a low voice and slow cadence, "Mr. Edison, if it were possible for you to hear the voice of any man whose name is known in the history of the world, whose voice would you prefer to hear?"

"Napoleon's," replied Edison without hesitation. 
Among his contemporaries working on the light bulb, Edison had a unique focus on commercialization of the emerging technology, rather than merely securing patents. ${ }^{160}$ Edison was no mere inventor, but a different breed altogether: the inventorentrepreneur. ${ }^{161}$ From the beginning, Edison intended not merely to license his light-bulb patents, but to commercialize the technology himself; indeed, much of his energies would be consumed in supervising the rollout of his products in the marketplace. ${ }^{162}$ In this way, he had much more in common with Steve Jobs or Bill Gates than with the average patent seeker.

As an entrepreneur, Edison understood that he would have to confront his competition in the marketplace sooner or later, no matter how advantageous his patent portfolio. ${ }^{163}$ He likely recognized the business advantages that come with being the first

"No, no," Stanley said piously, "I should like to hear the voice of our Savior."

"Well," explained Edison, "You know, I like a hustler."

Randall Stross, Edison the Inventor: Edison the Showman, N.Y. Times, Mar. 11, 2007, at B1. Strictly speaking, Edison's use of the word "hustler" describes Napoleon, not himself. But Edison's selection of Napoleon as the historical voice he would most like to hear strongly suggests that the inventor considered the empire-maker a personal role model. In describing Napoleon as a hustler, I believe Edison was also describing his vision of himself. It was a self-image successfully conveyed to others. Edison collaborator Francis Jehl would later celebrate Edison as the Napoleon of the team's efforts.

160. See PASSER, supra note 42, at 83 ("From the economist's viewpoint, the most significant aspect of Edison's activities in electric lighting was his concern at every step with economic factors."); see also HUGHEs, NETWORKS OF PowER, supra note 60, at 29 ("From the start, he clearly realized ... that his system would have to be economically competitive, and thus he conceived of the problem to be solved by invention as inseparably technical and economic.").

161. See Hughes, Networks of Power, supra note 60, at 18-22 (describing Edison's work as an inventor-entrepreneur). Harold C. Passer had earlier written of the engineer-entrepreneur, of which Edison was a leading example. See PASSER, supra note 42, at 356-60. "Edison was an engineer-entrepreneur on a full-time basis when he turned to the electric light. He made the move consciously and chose electric lighting as the best of a number of alternatives." Id. at 357.

162. See Hughes, Networks of Power, supra note 60, at 39-42 (explaining Edison's strategic design and location of the Pearl Street Station of the Edison Electric Illuminating Company in the financial district of New York City).

163. See PASSER, supra note 42, at 83 ("Nearly all of [Edison's] inventive activities were directed toward making his system as efficient as possible. If his system were to be successful ... it would have to survive the market test that every product in a free economic system has to meet."). 
to bring a product to market. Moreover, Edison was not just an experienced inventor and entrepreneur, he was also an experienced patent litigator, having participated in patent disputes related to many of his earlier inventions. Because of this past experience, Edison likely appreciated how difficult a task the courts would ultimately face in sorting out the competing patent claims surrounding incandescent light and realized that the party with greater market share and greater income would hold an important strategic advantage in the very expensive process of litigation.

Perhaps Edison ultimately won the patent war over electric light because, uniquely among the parties, he understood the true nature of the contest. Throughout the inventive race to the marketplace, each patent filing was merely a mile marker in an ultra-marathon of uncertain length. No one knew at the time of filing which patent claims would turn out to be key, once the market and the litigation began to take shape. ${ }^{164}$ This is not to say that patents were unimportant. They were stockpiled for the future, when the competition ultimately shifted from an inventive race to patent war. This battlefield was the true finish line, and the competition here took place as much on the dimensions of litigation and business strategy as on the technical merits. In retrospect, the initial patent race was not an athletic competition with a clearly defined finish line, allowing judges to objectively declare the winner. It was an arms race. ${ }^{165}$

\section{B. The Current Smartphone Patent War}

This Article's model of patent litigation, as resembling a game of Risk, was inspired by historical evidence. But the

164. See BRIGHT, supra note 2, at 86 (detailing the situation before the patent war began, stating that by 1887 the "validity of the patents granted in 1880 had not yet been tested"). See generally FELDMAn, RETHinking Patent LAW, supra note 68, at 40-74 (suggesting that this tremendous uncertainty as to future meaning and value at the time a patent is filed and granted is inherent to the nature of patent law).

165. For a more sophisticated exploration of the "arms race" metaphor in patent law, see Colleen V. Chien, From Arms Race to Marketplace: The Complex Patent Ecosystem and Its Implications for the Patent System, 62 Hastings L.J. 297, 303-11 (2011) 
metaphor of patent warfare has also recently been used to describe emerging litigation in the IT industry. According to competition and antitrust law scholar Michael Carrier, "The smartphone industry today is characterized by a thicket of patents and wars based on those patents. Every day brings a new lawsuit or development between Apple, HTC, Microsoft, Motorola Mobility (MMI), Nokia, and Samsung." 166 Carrier is neither the first nor the last to refer to the developing pattern of smartphone litigation as patent "warfare." 167 Journalists appear to have taken the cue for this military metaphor from the litigants themselves. ${ }^{168}$ As the metaphor suggests, the goal of this patent litigation is to crush the opponent and force surrender.

Ironically, this new patent war is breaking out in the very sector of the economy where patents may have played the smallest role in incentivizing innovation. When the computer industry first emerged in the 1960s, the United States Patent and Trademark Office (USPTO) resisted software patent applications as a matter of policy, ${ }^{169}$ and computer companies themselves

166. Carrier, supra note 4 , at 1.

167. See, e.g., McMillan, supra note 4 ("But in practice, patents are weapons. Technology companies load up on patents like Cold War nations stockpiling nuclear bombs, hoarding them for use when an important market is at stake."); Oberlander, Stabe \& Bernard, supra note 4 ("Patent wars are raging in the smartphone industry. What began as Apple v. Google Android conflict has turned into a vast legal quagmire involving everyone from Amazon to ZTE."); Vascellaro \& Ramstad, supra note 4 ("Chief executives ... will meet in San Francisco Monday in a court-directed session aimed at settling their smartphone patent war. But a deal seems unlikely, people familiar with the matter and others tracking the battle say.").

168. Software industry participants long spoke of defensive patenting; more recently, Steve Jobs famously invoked the metaphor of nuclear war in threatening a competing phone system. Peter Burrows, Apple Seen Hurting Shareholders Pursuing Jobs's Patent War: Tech, BloOMBERG (Dec. 28, 2011, 12:01 AM), http://www.bloomberg.com/news/2011-12-28/apple-seen-hurtingshareholders-with-jobs-s-thermonuclear-patent-war-tech.html (last visited Nov. 14, 2012) ("Steve Jobs, the co-founder of Apple (AAPL) Inc., told his biographer that he'd rather wage 'thermonuclear war' with Google Inc. than make deals to share its technology with the maker of the Android operating system.") (on file with the Washington and Lee Law Review).

169. See Pamela Samuelson, Benson Revisited: The Case Against Patent Protection for Algorithms and Other Computer Program-Related Inventions, 39 EMORY L.J. 1025, 1038-39 (1990) ("It was the [Patent Office] Commission's judgment that patent protection for computer program innovations was not desirable. The Commission's 1966 report... recommended legislation that expressly excluded computer programs from patent protection."). 
supported this approach. ${ }^{170}$ Even in the 1990s, some leading software firms opposed the granting of patents in their field. ${ }^{171}$ Software engineers also overwhelmingly expressed the view that patents were unnecessary and potentially harmful in their field. ${ }^{172}$ Nevertheless, the patentability of software has now been firmly established in the United States, and the number of software patent applications filed and granted has dramatically increased. ${ }^{173}$ Europe has been even slower than the U.S. to grant patent protection to software but is moving in the same direction. ${ }^{174}$ It is unclear whether the modern availability of

170. See id. at 1028 n.3 (describing industry input to the presidential commission in 1966); see also id. at 1143 (providing an overview of the early legal changes regarding the patentability of software).

171. See James Bessen, A Generation of Software Patents 2 (Bos. Univ. Sch. of Law, Working Paper No. 11-31, 2011), [hereinafter Bessen, Software Patents], available at http://ssrn.com/abstract=1868979 ("Major software firms opposed software patents through the mid-1990s." (citing Transcripts of the 1994 USPTO Software Patents Hearings, U.S. PATEnT \& Trademark Office, http://www. uspto.gov/web/offices/com/hearings/index.html (last visited Nov. 14, 2012))).

172. See Effy Oz, Acceptable Protection of Software Intellectual Property: A Survey of Software Developers and Lawyers, 34 INFo. \& MGMT. 161, 161-73 (1998); Pamela Samuelson et. al., Developments on the Intellectual Property Front, Communications of THE ACM, June 1992, at 33, 38 (stating that the responses to a 1989 survey taken by software developers suggested that there was "a significant opposition ... concerning patent protection for software innovations").

173. See James Bessen \& Robert M. Hunt, An Empirical Look at Software Patents, 16 J. Econ. \& MGMt. Strategy 157, 169 (2007) (stating that the number of patent applications granted per year has grown dramatically, and now "almost $15 \%$ of all patents granted are software patents"); Stuart J.H. Graham \& David C. Mowery, Intellectual Property Protection in the U.S. Software Industry, in Patents In The Knowledge-Based Econ. 219, 226-47 (Wesley A. Cohen \& Stephen A. Merrill eds., 2003) (examining judicial opinions and the shift to support the use of patents in software); Julie E. Cohen \& Mark A. Lemley, Patent Scope and Innovation in the Software Industry, 89 CAL. L. REV. 1, 7 (2001) ("[S]oftware's status as patentable subject matter was first doubted, then grudgingly admitted, and finally embraced.").

174. The European Patent Convention states that methods of "doing business[] and programs for computers" are not eligible for patent protection. European Patent Office [EPO], European Patent Convention art. 52(3), Oct. 5, 1973, 13 I.L.M. 268. That prohibition has been significantly modified, however, by more recent legal sources. The European Patent Office routinely grants software patents. See EPO, Guidelines for Examination in the European Patent Office, Part C, Chapter IV, $\S \S 2.1,2.2$ (June 2005) (indicating that the prohibition on the patentability of items under Art. 52(2) should be narrowly construed); see also Computer Program Product/IBM, T 1173/97-3.5.1 (EPO Bd. of App. July 1, 1998) (noting that "a computer program product is 
patent protection has produced any greater innovation in the software industry. ${ }^{175}$

Even under the newer pro-patenting rules, the prevailing dynamic of patenting in the software industry was "defensive"with companies seeking patent portfolios as leverage to protect themselves against suits by others. ${ }^{176}$ Strong patterns of crosslicensing and a "gentleman's agreement" not to sue kept the major firms from litigating their patents. ${ }^{177}$ In this context, it seemed that the major corporations had relegated patent law to an incidental role in the industry's business models. Mobile telephony was built upon collaborative industry standards relying on voluntary patent pooling. The Internet was built upon nonproprietary protocols. These were understood as deliberate choices made by industry consensus to limit the power of patent law and thereby avoid its negative consequences. ${ }^{178}$

Industry insiders and patent scholars alike assumed that the peace was secured by the logic of mutually assured destruction. Alex Blumberg and Laura Sydell summed up the conventional

not... excluded under all circumstances" under Article 52(2) and (3)). This leaves it up to each nation's courts to judge the validity of such patents in subsequent litigation. For a current overview of U.K. and German case law on the validity of software patents, see Susan J. Marsnick \& Robert E. Thomas, Drawing a Line in the Patent Subject-Matter Sands: Does Europe Provide a Solution to the Software and Business Method Patent Problem?, 34 B.C. INT'L \& Comp. L. REV. 227 (2011).

175. See generally Bessen, Software Patents, supra note 171 (drawing on empirical research to conclude that the spread of software patents has not produced greater innovation, only greater litigation). It should be noted, however, that software has long enjoyed copyright protection. The important difference is that copyright protection does not prevent competitors from reverse-engineering the same function, so long as they write original code.

176. See, e.g., Chien, supra note 165, at 303-10 (discussing the tendency of companies in the current software industry to pursue defensive patenting strategies); see also Baio, supra note 4 (recounting his participation in a software patenting effort he believed at the time was defensive, only to later find his firm at the center of offensive use of such patents).

177. Matt Macari, FRANDS Forever: How the Smartphone Industry Turned a Gentleman's Agreement into a Full-Scale Patent War, VERGE (Feb. 16, 2012, 4:01 PM), http://www.theverge.com/2012/2/16/2786970/FRAND-smartphoneindustry-apple-motorola-samsung (last visited Nov. 14, 2012) (on file with the Washington and Lee Law Review).

178. See id. (discussing the patent-licensing arrangements in the technology industry that sought to avoid patent law's negative impact). 
wisdom of industry insiders and followers when they reported in 2011:

All the big tech companies have started amassing troves of software patents-not to build anything, but to defend themselves. If a company's patent horde is big enough, it can essentially say to the world "If you try to sue me with your patents, I'll sue you with mine." It's mutually assured destruction. But instead of arsenals of nuclear weapons, it's arsenals of patents. ${ }^{179}$

By 2012, however, it became clear that the truce had broken down. What is less clear as this Article goes to press is what the consequences of this patent war will turn out to be. Will it indeed be mutual destruction? Or will one party emerge victorious, and with what damage to each side? And what will be the collateral damage to the public interest?

The smartphone patent war might be viewed as simply one more episode in the inevitable dynamics of economic uncertainty in a competitive marketplace. We might choose to remain confident in the legal system to sort things out properly, and in the markets to rebalance themselves. The lesson of the light-bulb war, however, cautions against such confidence. If history repeats itself in the smartphone patent war, we could once again see the consolidation of an important high-technology industry, with the attendant decline of competition. ${ }^{180}$ If one company establishes dominance in the smartphone sector, it will not only control the device itself but also have a market-dominant position from which to influence the markets for related services: mobile telephony, software, social networking, online advertising, mobile banking, and online retail. Smartphone dominance could be used to extract rents from and consolidate those related industries, subject only to the limits imposed by effective enforcement of antitrust law. ${ }^{181}$

179. Alex Blumberg \& Laura Sydell, When Patents Attack, NPR (July 22, 2011, 8:04 PM), https://www.npr.org/blogs/money/2011/07/26/138576167/whenpatents-attack (last visited Nov. 14, 2012) (on file with the Washington and Lee Law Review).

180. See supra Part IV.A (noting that the electric industry, following the patent warfare involving the light bulb, consolidated into General Electric, thus effectively preventing competition).

181. See Carrier, supra note 4 (discussing the role that antitrust law has begun to assume in limiting market dominance in the high-technology industry, 
To be sure, the fact that patent warfare led to effective monopoly in the early electrical industry is no guarantee that the same result will occur in the smartphone sector. The light bulb and the smartphone are different technologies, and these differences may produce different outcomes in the two industries. It is also possible that reforms in patent and antitrust law since the turn of the century have lowered the risks for this kind of patent-precipitated consolidation of a market. Nevertheless, the very fact that a similar pattern of patent warfare is exhibited in two very different industries, at two very different points in time, suggests significant commonalities. Rather than adopt a waitand-see approach when so much may be on the line, what can be done proactively to reduce the risk of consolidation and loss of competition in the smartphone industry?

At least one federal judge has already flagged the risk that patent litigation poses to industry competition and consumer welfare in the smartphone sector. ${ }^{182}$ In June 2012, Judge Richard A. Posner issued a remarkable ruling in a particularly highprofile smartphone patent suit between Apple and Motorola (which was acquired by Google in August 2011). ${ }^{183}$ Judge Posner indicated his intention to dismiss the suit with prejudice without granting a jury trial, on the grounds that, even if the disputed patents were valid and infringed, there was insufficient evidence to support damages, and injunctive relief would be counter to the public interest.184 This holding may be interpreted as clever procedural handling by Judge Posner to squash a case in which one or both parties were attempting to misuse patent law to damage its competitor company out of proportion to any real harm done. On the heels of the decision, Judge Posner-acting in his capacity as a law professor-also initiated a media effort to

both in the United States and in Germany).

182. See Posner, Too Many Patents, supra note 4 (noting the potential risks of certain patenting tactics).

183. Judge Posner is one of a number of Article III judges specially designated as volunteers to hear patent disputes at the trial court level, having received special training in the handling of these complex cases.

184. Apple, Inc. v. Motorola, Inc., No. 1:11-cv-08540 (N.D. Ill. June 7, 2012), available at http://www.scribd.com/doc/96427053/Posner-Order, Opinion and Order of June 7, 2012 (on appeal Fed. Cir.). 
highlight the potential of patent law to damage competition and innovation, calling for dramatic patent reform. ${ }^{185}$

The suit before Judge Posner, however, was just one among many. In August 2012, Judge Lucy Koh presided over a highly publicized trial brought by Apple in the Northern District of California. ${ }^{186}$ The lawsuit targeted Samsung, the leading manufacturer of smartphones running Android software, which were increasingly overtaking the Apple iPhone in popularity. ${ }^{187}$ After just three days of deliberation, the jury found Samsung to have infringed Apple's utility patents, design patents, and trade dress. ${ }^{188}$ The jury awarded over $\$ 1$

185. See, e.g., Posner, Too Many Patents, supra note 4 (discussing the negative consequences of patent law).

186. Apple Inc., v. Samsung Elecs. Co., No. 11-CV-01846-LHK, 2012 WL 3627731 (N.D. Cal. Aug. 21, 2012).

187. Apple had an early advantage in the smartphone market because of lead-time and network effects. Apple encouraged independent software developers to produce "apps" that could run on Apple's iOS system. The availability of these apps became a major feature driving consumers to purchase the iPhone. None of the competing smartphone manufacturers commanded sufficient market penetration to attract similar app development, until Google introduced the Android operating system. Google widely licensed the Android software to a number of smartphone manufacturers, including Samsung. The emergence of the Android platform enabled other manufacturers to effectively compete with the iPhone. By mid-2011, Android phones were outselling iPhones more than two-to-one. See IDC, Android and iOS Surge to New Smartphone OS Record in Second Quarter (Aug. 8, 2012), http://www.idc.com/getdoc.jsp? containerId=prUS23638712 (last visted Oct. 21, 2012) (reporting Q2 2011 shipments of 50.8 million Android phones and 20.4 million iOS phones) (on file with the Washington and Lee Law Review). By the middle of 2012, however, the gap had widened; four Android phones were being sold for each iPhone. See id. (reporting Q2 2012 shipments of 104.8 million Android phones and 26.0 million iOS phones.) At the time of the trial, Samsung was the leading producer of Android phones. See id. ("Android's success in the market can be traced directly to Samsung, which accounted for $44.0 \%$ of all Android phones shipped [worldwide] in [the second quarter of 2012] and totaled more than the next seven Android vendors' volumes combined.").

188. See Amended Verdict Form, Apple Inc., v. Samsung Elecs. Co., No. 11CV-01846-LHK (N.D. Cal. Aug. 21, 2012) [hereinafter Amended Jury Verdict Form], available at http://cand.uscourts.gov/filelibrary/1079/Amended\%20Jury\% 20Verdict.pdf; Dan Levine, Jury Didn't Want to Let Samsung Off Easy in Apple Trial: Foreman, REUTERS (Aug. 25, 2012, 3:51 PM), http://www.reuters.com/article/ 2012/08/25/us-apple-samsung-juror-idUSBRE87O09U20120825 (last visited Nov. 14, 2012) [hereinafter Levine, Apple Trial] ("A nine-member jury found the Korean company had infringed on several Apple features and design patents ....") (on file with the Washington and Lee Law Review). 
billion in damages. ${ }^{189}$ Having tested the appeal of their claims before one jury, Apple has probably gained a stronger hand to negotiate concessions from other smartphone manufacturers running the Android system. This case was unique, however, in that the accused products not only incorporated software features described by Apple's utility patents but were also very similar in external appearance. This latter fact led to infringement claims based on Apple's design patents and on a theory of trade dress dilution. ${ }^{190}$ The jury was not asked to distinguish the damages it attributed to each theory of infringement. ${ }^{191}$ A different result might thus be reached in another case in which the products were not similar in external appearance.

The Federal Circuit has also shown an inclination to lower the stakes of the smartphone patent war by making it increasingly difficult to block a competitor's phone on the basis of a minor software patent. For many years, courts routinely awarded not only monetary damages but also an injunction against future sales of the infringing product, whenever the patent holder prevailed on the merits. ${ }^{192}$ This created a problem of "patent holdup," whereby patents on minor features could be used to block the sale of an entire product. ${ }^{193}$ The Supreme

189. See Amended Jury Verdict Form, supra note 188, at 15 (stating the damages awarded to Apple); Levine, Apple Trial (awarding a jury verdict of $\$ 1.05$ billion dollars, which could be tripled because the jury found the company acted willfully).

190. The San Jose jury concluded that the iPhone trade dress (registered and unregistered) was famous and was willfully diluted by Samsung's products. See Amended Jury Verdict Form, supra note 188, at 10-12, 14.

191. See Amended Jury Verdict Form (asking jurors to answer "yes" or "no" for whether each accused product violated each patent and the trade dress, and also "[w]hat is the total dollar amount that Apple is entitled to receive from Samsung on the claims on which you have ruled in favor of Apple?").

192. See, e.g., MercExchange, L.L.C. v. eBay Inc, 401 F.3d 1323, 1339 (Fed. Cir. 2005) (granting an injunction and restating the "general rule that courts will issue permanent injunctions against patent infringement absent exceptional circumstances"), rev'd, 547 U.S. 388 (2006).

193. See Colleen V. Chien \& Mark A. Lemley, Patent Holdups, the ITC, and the Public Interest, 98 CORNELL L. REV. 105-06 (forthcoming Nov. 2012), available at http://ssrn.com/abstract $=2022168$

In a common patent infringement case, for example, the patent covers a small part of a larger product, and the defendant infringes it inadvertently. If an interoperability standard covers the infringing feature, removing the feature may disable the product. Eliminating a 
Court's 2006 decision in Ebay v. MercExchange ${ }^{194}$ questioned the routine grant of injunctive relief in patent cases and called for a more demanding inquiry into the equities of each case. ${ }^{195}$ In the wake of this case, lower courts have been more inclined to deny injunctive relief, even where a patent holder seems likely to prevail on the merits.

In the Apple-Samsung case described above, Judge Koh refused to enjoin the sale of four Samsung products in December 2011, despite holding that Apple was likely to prevail in proving patent infringement. ${ }^{196}$ Koh reasoned that Apple had failed to prove a sufficient "nexus" between the patent Samsung infringed and the alleged harm of lost iPhone sales. ${ }^{197}$ On appeal, the

big product from the market because of a small patent harms consumers, and blocking a large number of lawful components and features from the market along with the infringing one distorts competition.

In another common situation, a patent holder sues a large number of companies, threatening to hobble an entire industry. An injunction would exclude many participants from the marketplace and dramatically reduce competition.

In both these scenarios, the harm to consumers and competition from an exclusion order is greater than the contribution made by the individual infringing component.

194. eBay Inc. v. MercExchange, L.L.C., 547 U.S. 388 (2006).

195. See id. at 393-94 (holding that injunctive relief was inappropriate based on a case-specific analysis of four equitable factors); see also Winter v. Natural Res. Def. Council, Inc., 555 U.S. 7, 20 (2008) (applying the MercExchange standard to deny a preliminary injunction in a case not related to patent law).

196. Apple, Inc. v. Samsung Elecs. Co., No. 11-CV-01846-LHK, 2011 WL 7036077, at *40 (N.D. Cal. 2011) ("For the forgoing reasons, the Court DENIES Apple's motion to preliminarily enjoin the sale in the United States of the Samsung Infuse 4G, the Samsung Galaxy S 4G, the Samsung Tab 10.1, and the Droid Charge phone."), aff'd in part, vacated in part, remanded, 678 F.3d 1314 (Fed. Cir. 2012).

197. See id. at *20-21, *39-40. Judge Koh explained her decision with reference to the "leveraging" reasoning offered in $e$ Bay:

Even though Apple has shown Samsung's products likely infringe Apple's valid '381 patent, and that Apple and Samsung compete in the same market for new smartphone customers and for tablet computer consumers, Apple has offered no evidence that Samsung's infringement of the '381 patent is likely to cause irreparable harm. ... Indeed, Apple has failed to establish a relationship between any alleged loss of market share, customers, or goodwill, and the infringement of the '381 patent. 
Federal Circuit endorsed Koh's articulation and application of a nexus requirement. ${ }^{198}$ Following this guidance, Judge Koh again conducted a nexus analysis in June 2012, in the second case brought by Apple against Samsung in her court. ${ }^{199}$ This time, Koh found the nexus requirement to be satisfied and granted an injunction barring sales of Samsung's Galaxy Nexus smartphone. ${ }^{200}$ Judge Koh held that Apple had met its burden of proof with respect to one particularly important patent, U.S.

Justice Kennedy, in his concurring opinion in eBay, instructed courts to be cognizant of the nature of the patent being enforced and the economic function of the patent holder when applying the equitable factors:

When the patented invention is but a small component of the product the companies seek to produce and the threat of an injunction is employed simply for undue leverage in negotiations, legal damages may well be sufficient to compensate for the infringement and an injunction may not serve the public interest.

The Court finds this argument persuasive. While Apple undoubtedly uses the patent and produces goods in the same market, Apple has neither alleged, nor established, that the '381 patent is either necessary to, or a core functionality of, the products that it seeks to enjoin. Nor has Apple shown that consumers' purchasing decisions are based on the existence of a snap back feature protected by the '381 patent.

Id. at *39-40 (citations omitted).

198. See Apple, Inc. v. Samsung Elecs. Co., 678 F.3d 1314, 1324 (Fed. Cir. 2012)

We hold that the district court was correct to require a showing of some causal nexus between Samsung's infringement and the alleged harm to Apple as part of the showing of irreparable harm. To show irreparable harm, it is necessary to show that the infringement caused harm in the first place. Sales lost to an infringing product cannot irreparably harm a patentee if consumers buy that product for reasons other than the patented feature. If the patented feature does not drive the demand for the product, sales would be lost even if the offending feature were absent from the accused product. Thus, a likelihood of irreparable harm cannot be shown if sales would be lost regardless of the infringing conduct.

199. See Apple Inc., v. Samsung Elecs. Co., No. 12-CV-00630-LHK, 2012 WL 257203 (N.D. Cal. July 1, 2012), rev'd, No. 2012-1507, 2012 WL 4820601 (Fed. Cir. 2012).

200. See id. The "Nexus" phone was thus saved by the "nexus" requirement. This may not be a complete linguistic coincidence. Although other courts had previously articulated this concept, Judge Koh appears to be the first to use the term "nexus" to describe it. 
Patent No. 8,086,604, which was related to the iPhone's "Siri" personal assistant feature. ${ }^{201}$

In October 2012, however, the Federal Circuit ruled on appeal that the Galaxy Nexus injunction was improperly granted. ${ }^{202}$ The Federal Circuit insisted that the nexus requirement be applied even more stringently. According to the circuit-level opinion, Apple had failed to demonstrate that the infringement drove consumer demand for the Galaxy Nexus because Samsung's feature incorporating the '604 patent was not among the top five reasons that consumers choose that phone. ${ }^{203}$ Articulated in this way, the Federal Circuit's "causal nexus" standard seems extremely difficult to satisfy, at least in the context of smartphones. This ruling may signal the end of the injunction as a weapon in the smartphone patent war.

Even as the Federal Circuit has made it more difficult to block a competitor's phone through the courts, however, litigants are looking to other venues. Colleen Chien and Mark Lemley point out that patent holders are increasingly circumventing the new higher standards for injunctive relief by taking their cases to the International Trade Commission (ITC) instead. ${ }^{204}$ The ITC is a U.S. administrative agency that is empowered to issue "exclusion orders" blocking products it deems to be infringing from entering the U.S., achieving the same result as an injunction. According to Chien and Lemley, the ITC is increasingly the battleground of choice in the smartphone patent war and continues to be liberal in granting exclusion orders. ${ }^{205}$

Given the myriad of patents relevant to smartphone technology, an aggressive and persistent litigator can launch

201. See id. at *55-56.

202. See Apple Inc., v. Samsung Elecs. Co., No. 2012-1507, 2012 WL 4820601 (Fed. Cir. 2012).

203. See id. at *10-11 ("Apple's own survey evidence shows that unified search is not one of the top five reasons consumers select Android smartphones. In this light, the causal link between the alleged infringement and consumer demand for the Galaxy Nexus is too tenuous to support a finding of irreparable harm.").

204. See Chien \& Lemley, supra note 193, at 102-03. ("[T]he ITC is busier with patent cases than it ever has been before.").

205. See id. at n.15 (citing individual cases involving Apple, Samsung, Sony, LG, HTC, Motorola, Nokia, and RIM). "In 2011, every major smartphone maker was embroiled in an ITC dispute." Id. at 104. 
many volleys and advance through attrition. Edison's own litigation campaign met with modest success for many years, until he achieved a surprising victory in a German court, which then formed the basis for the next round of decisive litigation in the U.S. Similarly, the smartphone patent war is now being waged on many fronts, with suits active in England, Germany, South Korea, Japan, and elsewhere, and is far from over. ${ }^{206}$

\section{Implications for Innovation}

Supplementing the theory of patent racing with a theory of patent warfare casts a more skeptical light on the innovation hypothesis. The initial fervor to claim patent rights in the early electrical industry stimulated greater investment in firstgeneration research. ${ }^{207}$ This is consistent with the predictions of Lemley's patent racing theory. ${ }^{208}$ Over the long term, however, patent protection also led to a dramatic reduction of competition in the electrical industry. ${ }^{209}$ As the industry matured, the more well-funded companies used patent warfare to target and eliminate their competition. ${ }^{210}$ Regardless of who emerges as the winner in Risk, the endgame is always the same: one party controls the entire board. In the real-life version, there may also be a détente where two parties agree to tolerate each other in separate spheres-as General Electric and Westinghouse divided the U.S. and British markets. Either way, the very competition that stimulated faster innovation during the racing stage is ultimately brought to an end.

206. See Carrier, supra note 4, at 3 (noting the importance of the German courts with respect to patent law).

207. See supra Part III.B (supporting the proposition that the initial fervor to claim patent rights stimulated substantial investment in first-generation research).

208. See supra Part III.A-B (noting Lemley's predictions and discussing how the historical record of the beginnings of light bulb inventing is consistent with Lemley's predictions).

209. See supra Part IV.A (noting the negative effects of patent law on industry research).

210. See supra Part IV.A (discussing the tactics of well-funded companies to use patent litigation to eliminate competition). 
Patent warfare may harm innovation in at least three ways. First, litigation is a resource-intensive distraction of capital and human resources. The Edison interests, for example, spent $\$ 2$ million on litigation ${ }^{211}$ at a time when the company's net worth was only $\$ 12$ million. ${ }^{212}$ These financial resources, as well as Edison's own talents, might otherwise have been invested in improving the product and delivering it more efficiently to consumers. Second, a litigious environment can discourage the risk-taking of investing in next-generation innovation because would-be innovators fear they will be legally prevented from producing the newer technology. Third, as the pressure to stay one step ahead of the competition is eased, the competitive motivation to keep improving the technology is diminished. Bright notes this dynamic in the early electrical industry: as the light bulb litigation heated up, technological innovation dimmed. ${ }^{213}$ In the aftermath of patent warfare, General Electric was able to prevent any other light bulb manufacturer from exerting downward pressure on prices; the only real competitive pressure came from further advances in the substitute technology of gas lighting. ${ }^{214}$ This is not to say that light bulb innovation ground to a halt. General Electric still had profit-based incentives to cut its own production costs by introducing more efficient technological improvements. ${ }^{215}$ But the company no longer risked

211. See BRIGHT, supra note 2, at 86 (estimating that "[b]etween 1885 and 1901 the Edison company and its successors spent about $\$ 2,000,000$ on well over two hundred infringement suits under its lamp and lighting patents"). Defendants of the lawsuits probably had to spend nearly the same amount.

212. See id. ("The final step in the transition of the Edison companies from domination by Thomas A. Edison to domination by financiers took place in 1889 [merging] the remaining separate Edison development and manufacturing companies into the Edison General Electric Light Company.... The new company had a capitalization of $\$ 12,000,000 \ldots$. .").

213. See id. at 138 (indicating that "[t]he lengthy and expensive patent struggle in the lamp industry from 1885 to 1894 was a serious damper on progress in lamp design, although process improvement continued").

214. See id. at 457 (discussing the realities surround General Electric's dominance, including the volume of the market controlled by General Electric, the lack of developmental work available to competitors, and the generally passive role licensees).

215. See id. at 455 (noting that General Electric "possessed immense ability to achieve technological advances... [and]... had strong incentives to make improvements in lamp design and production methods"). 
being overtaken by a competitor if it lagged behind in the innovative endeavor. As competition in the electric industry slowed and prices for equipment and service remained high, millions of Americans literally waited in the dark. More than a half-century would pass after Thomas Edison filed his first patents before electric light would find its way into the average American home.

Importantly, the potential long-term damage to nextgeneration innovation is not limited to the twenty years of the modern patent term. By the time first-generation patents become obsolete, newer patents already exist to take their place. When Edison's patents expired, General Electric was able to use newer ones to extend its dominance. ${ }^{216}$ The result in the case of the light bulb was that General Electric would control the electric lighting industry for many decades longer. ${ }^{217}$ Even as Arthur A. Bright published his thesis on the electric-lamp industry in 1949, General Electric's monopolization of the electric lighting industry remained a problem. Once patent warfare produces the consolidation of an industry, reintroducing competition is not a simple matter.

This anticompetitive endgame is my central concern with the use of patent racing theory as a new justification for patent protection. The racing metaphor paints a picture of objectivity and fair competition. In the case of the light bulb, however, the race was merely a prelude to the war. Patents almost certainly add fervor to inventive races at a certain stage of research and development. But at a later stage, patents also become weapons that competitors use to threaten and dominate their competition, long before the public policy goal of wide diffusion of the new technology has been fully attained. This may also have the perverse effect of ultimately limiting next-generation innovation. In the end, enthusiasm for the competitive advantages of races may be an argument against patent protection, rather than an argument in its favor.

216. See id. at 458 (noting General Electric's ability to exert control over the patent market).

217. See id. at 458-60 (noting General Electric's ability to exert control until World War II "with the aid of a strong patent position, commercial and technical aggressiveness, strong control over lamp parts and machinery, extensive advertising, and good public relations"). 
The story of the light bulb thus turns out to be a cautionary tale against reliance on the innovation assumption. The downsides of patent protection are probably systematically underappreciated. Partly this has to do with our methodology of study. Empirical study of recent fields of technology is best at highlighting the initial, short-term impacts of patent protection. These include assistance in recruiting capital to fund research and product development, and in outsourcing production chainsboth of which are positives for innovation. Only historical study can reveal the longer-term impacts that patent litigation produces on an industry. These may be systematically more negative as patents become weapons in attempts to monopolize a field. ${ }^{218}$ Further research is needed to determine whether patent wars are typical or exceptional features of technological development in the shadow of patent law, identify what factors motivate different outcomes in patent wars, and clarify the impact of industrial consolidation on next-generation innovation as well as diffusion.

\section{Conclusion}

Although patent law is founded on the assumption that patent protection encourages innovation, there is little empirical support available to test this "innovation hypothesis." This Article has argued that historical case studies can offer a stronger empirical basis for patent scholarship by illuminating the true impact of patent law on innovation throughout the life of a patent term. The present case study demonstrates this potential, both by suggesting refinements to one theory of patent racing, and by proposing a new theory of patent warfare resembling the board game Risk. Patent warfare transformed the electrical industry at the close of the nineteenth century and has now erupted in the smartphone sector. The case study of the light bulb shows that patent law can have both positive and negative impacts on technological innovation, and we ignore the complexity of these dynamics at our own peril.

218. See supra Part II.B (noting case studies of patenting that support the proposition that patent law harms industry and innovation). 